Published in final edited form as:

J Org Chem. 2008 June 6; 73(11): 4175-4185.

\title{
Synthesis of 5,15-Diaryltetrabenzoporphyrins
}

\author{
Mikhail A. Filatov ${ }^{\dagger}$, Artem Y. Lebedev $^{\ddagger}$, Sergei A. Vinogradov ${ }^{\star}, \ddagger$, and Andrei V. Cheprakov ${ }^{\star}, \dagger$ \\ $\dagger$ Department of Chemistry, Moscow State University, Moscow 119899, Russia \\ \$Department of Biochemistry and Biophysics, University of Pennsylvania, Philadelphia, Pennsylvania 19104
}

\begin{abstract}
A general method of synthesis of 5,15-diaryltetrabenzoporphyrins ( $\left.\mathrm{Ar}_{2} \mathrm{TBPs}\right)$ has been developed, based on $2+2$ condensation of dipyrromethanes followed by oxidative aromatization. Two pathways to $\mathrm{Ar}_{2} \mathrm{TBPs}$ were investigated: the tetrahydroisoindole pathway and the dihydroisoindole pathway. In the tetrahydroisoindole pathway, precursor 5,15-diaryltetracyclohexenoporphyrins (5,15$\mathrm{Ar}_{2} \mathrm{TCHPs}$ ) were assembled from cyclohexeno-fused meso-unsubstituted dipyrromethanes and aromatic aldehydes or, alternatively, by way of the classical MacDonald synthesis. In the first case, scrambling was observed. Aromatization by tetracyclone was more effective than aromatization by DDQ but failed in the cases of porphyrins with electron-withdrawing substituents in the meso-aryl rings. The dihydroisoindole pathway was found to be much superior to the tetrahydroisoindole pathway, and it was developed into a general preparative method, consisting of (1) the synthesis of 4,7-dihydroisoindole and its transformation into meso-unsubstituted dipyrromethanes, (2) the synthesis of 5,15-diaryloctahydrotetrabenzoporphyrins (5,15- $\mathrm{Ar}_{2} \mathrm{OHTBPs}$ ), and (3) their subsequent aromatization by DDQ. $\mathrm{Ar}_{2} \mathrm{TBP}$ free bases exhibit optical absorption spectra similar to those of meso-unsubstituted tetrabenzoporphyrins and fluoresce with high quantum yields. Pd complex of $\mathrm{Ph}_{2} \mathrm{TBP}$ was found to be highly phosphorescent at room temperature.
\end{abstract}

\section{Introduction}

$\pi$-Extended porphyrins form a class of porphyrinoids in which pyrrole rings are fused with external aromatic fragments via the $\beta$-carbon atoms. The best known representatives of this class are symmetrically $\pi$-extended porphyrins, such as tetrabenzoporphyrins and tetranaphthoporphyrins, whose optical and other properties attract interest in materials research, ${ }^{1}$ biomedical imaging and sensing, ${ }^{2}$ up-conversion of noncoherent NIR light, ${ }^{3}$ and photodynamic and boron neutron-capture therapy. ${ }^{4}$

Until recently, synthetic approaches to tetrabenzo- and tetranaphthoporphyrins were limited by the so-called "template condensation" method and variants thereof, 5 which require severe reaction conditions and prohibit introduction of many useful functionalities into the macrocycle. In the search for more practical approaches, efforts were mainly directed toward tetraarylated tetrabenzo- and tetranaphthoporphyrins ( $\mathrm{Ar}_{4} \mathrm{TBPs}$ and $\left.\mathrm{Ar}_{4} \mathrm{TNPs}\right)$, whose modification can be conveniently accomplished via the meso-aryl rings. The method employing oxidative aromatization ${ }^{6}$ has emerged as a straightforward and $\operatorname{Ar}_{4} \mathrm{TNPs}^{8}$ and practical approach to $\mathrm{Ar}_{4} \mathrm{TBPs}^{7}$ The synthesis in this route proceeds via the well-established

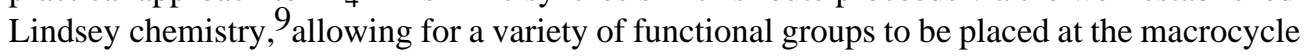

\footnotetext{
*vinograd@mail.med.upenn.edu; avchep@elorg.chem.msu.ru

Supporting Information Available: Additional procedures, details of photophysical experiments, and characterization data for the new compounds. This material is available free of charge via the Internet at http://pubs.acs.org.
} 
periphery. This strategy was later extended on the synthesis of meso-unsubstituted tetrabenzoand tetranaphthoporphyrins (TBPs and TNPs). ${ }^{10}$

Recently, a useful extension of the oxidative aromatization method was developed, which is based on a convenient precursor, 4,7-dihydroisoindole. ${ }^{11}$ Using this method, we synthesized and for the first time unambiguously characterized meso-5,15-diphenyltetrabenzoporphyrin, 12 the simplest representative of the class of 5,15-diaryltetrabenzoporphyrins $\left(\mathrm{Ar}_{2} \mathrm{TBP}\right.$, Chart 1). ${ }^{13}$ It appeared that the optical absorption spectrum of free base 5,15- $\mathrm{Ph}_{2} \mathrm{TBP}\left(\mathrm{H}_{2} \mathrm{Ph}_{2} \mathrm{TBP}\right)$ strongly resembled the spectra of meso-unsubstituted $\mathrm{H}_{2}$ TBPs, ${ }_{10,14}$ suggesting that $\mathrm{H}_{2} \mathrm{Ar}_{2}$ TBPs also possess undistorted planar geometries 15 and highly emissive excited states. $2 \mathrm{a}, 14,16$ The combination of the red absorption, strong emissivity, and ease of functionalization suggests that $\mathrm{Ar}_{2}$ TBPs can be utilized in a wide variety of applications, including biomedical imaging, optical sensing, and PDT.

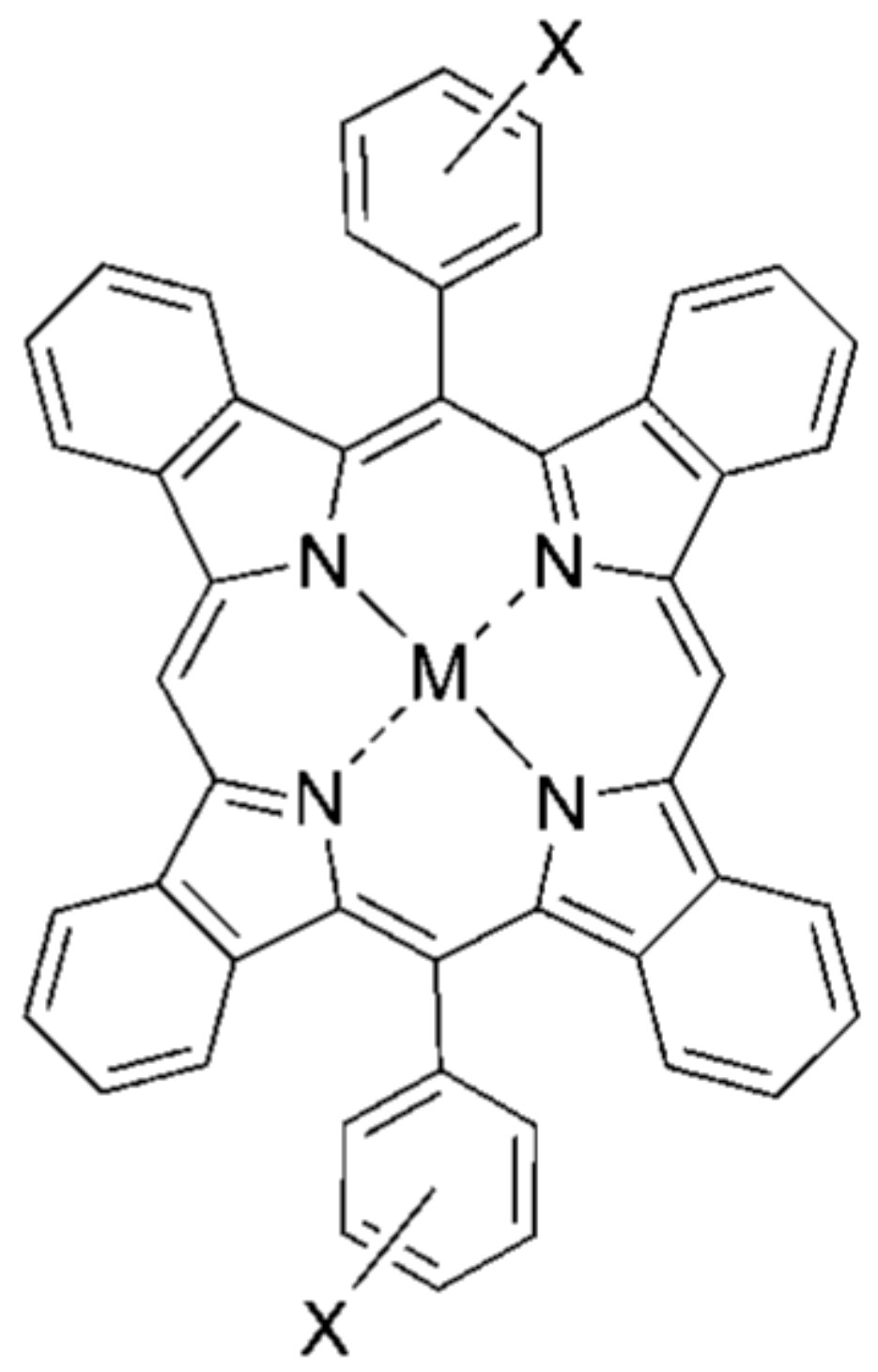

\section{CHART 1.}

5,15-Diaryltetrabenzoporphyrin $\left(\mathrm{Ar}_{2} \mathrm{TBP}\right)$ 
In addition to forming a distinct group among $\pi$-extended porphyrins, $\mathrm{Ar}_{2} \mathrm{TBPs}$ belong to a much wider family of meso-5,15-diarylporphyrins $\left(\mathrm{Ar}_{2} \mathrm{Ps}\right) . \mathrm{Ar}_{2} \mathrm{Ps}$ have been known since $1968,{ }^{17}$ and over the years, they have become one of the most widely used building blocks for construction of porphyrin-based macrostructures. The latter include, but are not limited to, porphyrin dimers, ${ }^{18}$ linear ${ }^{19}$ and branched ${ }^{20}$ arrays, models of the photosynthetic antenna and reaction center, ${ }^{21}$ supramolecular assemblies, ${ }^{22}$ strapped porphyrins, including biomimetic models, ${ }^{23}$ porphyrin-based catenanes and rotaxanes, ${ }^{24}$ dyads and triads in combination with other electro- and/or optically active fragments, 25 and scaffolds for chiral organopalladium complexes. ${ }^{26} \mathrm{Ar}_{2} \mathrm{Ps}$ have also been studied as agents for $\mathrm{PDT}, 27$ recognition motifs for aminoacids and other small molecules, ${ }^{28}$ cores for dendrimers, ${ }^{29}$ and ligands for DNA intercalation. 30

Given such an overwhelming array of applications, it appeared interesting and relevant to complement the $\mathrm{Ar}_{2} \mathrm{P}$ family by their $\pi$-extended relatives, which on one hand bear the key structural features of $\mathrm{Ar}_{2} \mathrm{P}$ but on the other hand possess distinctly different optical properties. In this paper, we report a detailed account on the synthesis of $\mathrm{Ar}_{2} \mathrm{TBPs}$ with variously substituted meso-aryl groups, suitable for further functionalization.

\section{Results and Discussion}

\section{Synthesis of $\mathrm{Ar}_{2}$ TBPs via Tetrahydroisoindole Route. Assembly of Precursor Porphyrins ( $\left.\mathrm{Ar}_{2} \mathrm{TCHPs}\right)$}

Initially, we examined the approach to $\mathrm{Ar}_{2} \mathrm{TBPs}$ via aromatization of 5,15-

diarylhexadecahydrotetrabenzoporphyrins or, simpler, 5,15-

diaryltetracyclohexenoporphyrins ( $\mathrm{Ar}_{2} \mathrm{TCHPs}$ ), using the methodology developed earlier for $\mathrm{Ar}_{4}$ TBPs and TBPs. ${ }^{7,8} \mathrm{Ar}_{2}$ TCHPs can be assembled using either of the two orthogonal pathways, $\mathbf{A}$ and $\mathbf{B} / \mathbf{B}$ ', depicted in Scheme 1.

Route $\mathbf{A}$ is based on the acid-catalyzed condensation of meso-unsubstituted dipyrromethanes with aromatic aldehydes. ${ }^{17,31}$ This route has been used in the past for preparation of various types of 5,15-diaryloctaalkylporphyrins. ${ }^{21,31 b, 32}$ The alternative route has two major variants: B, the classical MacDonald's method, ${ }^{33}$ in which the substituent-free methine groups in the target porphyrin originate from the formyl groups in 1,9-diformyldipyr-romethanes, and B', the method of Baldwin et al., ${ }^{34}$ which makes use of the condensation of 1,9-unsubstituted 5 -aryldipyrromethanes with orthoformate. A variant of the latter reaction, employing $\mathrm{N}, \mathrm{O}$ acetal of formaldehyde $\left(\mathrm{EtOCH}_{2} \mathrm{NBn}_{2}\right)$, has been used to synthesize $\mathrm{Ar}_{2} \mathrm{TCHPs}, 35$ but the practical value of this method was undermined by a significant degree of scrambling.

Our goal was to establish the simplest, most versatile approach to $\mathrm{Ar}_{2} \mathrm{TCHPs}$ and, at the same time, allow alternative protection-deprotection schemes in the syntheses of intermediate pyrrole derivatives, permitting different types of sensitive peripheral functionalities. 36 Potentially, approach A could lead to scrambling since formation of the methylene bridges between pyrrole residues is reversible under acidic conditions. ${ }^{37}$ Nevertheless, this route appeared more simple and straightforward, as it required only one dipyrromethane derivative.

In route $\mathbf{A}$, meso-unsubstituted dipyrromethane $\mathbf{3}$ was synthesized in high yield using a published procedure ${ }^{38}$ from readily available tetrahydroisoindole ester $1 \mathbf{a}^{39}$ and introduced into the condensation with aromatic aldehydes to afford $\mathrm{Ar}_{2}$ TCHPs $4 \mathbf{a}-\mathbf{e}$ in good overall yields (Scheme 2).

MALDI-TOF MS analysis revealed that in the majority of cases scrambling was insignificant, and only small amounts of "defective" porphyrins (i.e., monoaryl- or meso-unsubstituted) could be detected in reaction mixtures. However, in the case of strongly electrophilic 
pentafluorobenzaldehyde, extensive scrambling occurred, yielding a mixture of porphyrins with one, two, or no meso-aryl groups. As a result, porphyrin $4 \mathbf{e}$ could not be isolated in the pure form.

The classical MacDonald's synthesis (pathway B in Scheme 1) requires two dipyrromethane derivatives: dialdehyde and diacid. The common precursors of both components are tert-butyl esters of 5-aryldipyrromethane-1,9-dicarboxylic acids 5a-c, which were synthesized as shown in Scheme 3.

The yields of esters $\mathbf{5 a - c}$ could be improved significantly in the presence of anhydrous tetrabutylammonium chloride. Condensation of pyrrole-2-carboxylates with aldehydes usually results in yields not exceeding $60-70 \%$, which is likely to be caused by side reactions, promoted by strong acids in the presence of the liberated water. Addition of anhydrous $\mathrm{Bu}_{4} \mathrm{NCl}$, a highly hygroscopic compound, raised the yields of dipyrromethanes 5a-c nearly up to quantitative, suggesting the salt effected water scavenging. ${ }^{40}$ Notably, in the original MacDonald synthesis, water was sometimes removed by azeotropic distillation. 41

Diesters 5a-c were further converted into 1,9-unsubstituted dipyrromethanes 6a-c or, alternatively, ipso-formylated to give 1,9-diformyldipyrromethanes 7a-c for the following porphyrin synthesis. Since the synthesis of $6 \mathbf{a}-\mathbf{c}$ and the Lindsey reaction ${ }^{9}$ required practically the same conditions, 6a-c could be used without isolation and purification. The acid-catalyzed ester cleavage/decarboxylation of 5a-c was followed by the immediate addition of diformyldipyrromethanes 7a-c and oxidation by DDQ to afford target porphyrins $4 \mathbf{4 a - c}$ in good yields.

MALDI MS analysis of the crude reaction mixtures containing 4a-c did not reveal any traces of scrambling. Notably, condensation of diformyldipyrromethane with dipyrromethane gives porphodimethene, ${ }^{42}$ but not porphyrinogen - the key intermediate in the type A condensations (Scheme 1). Porphodimethenes are expected to be much more stable toward the acid-catalyzed cleavage. Unlike porphyrinogens, whose fission is initiated by protonation of their $\alpha$-carbons, porphodimethenes contain more basic nitrogen atoms in the azafulvene rings (Scheme 4). ${ }^{43}$ Besides, even if the ipso-protonation was to occur, it would result in an unfavorable $\sigma$-complex, destabilized by the pyrrolenine nitrogen on the conjugation path.

For comparison, we have implemented the standard Mac-Donald's protocol, for which dipyrromethanes $\mathbf{6}$ and $\mathbf{7}$ had to be isolated and purified. Overall, this method appeared to be less efficient, as it was more labor intensive and fraught with losses due to the poor stability of 1,9-unsubstituted dipyrromethanes.

Aromatization of $\mathrm{Ar}_{2}$ TCHPs Using DDQ-Conversion of tetracyclohexenoporphyrins into tetrabenzoporphyrins requires removal of 16 hydrogens by way of oxidative aromatization. 6 For this reaction, $\mathrm{Ar}_{4}$ TCHPs need to be first transformed into their metal complexes, ${ }^{7 \mathrm{a}}$ whereas meso-unsubstituted TCHPs can be converted into TBPs with or without metalation. 10

Our attempts to synthesize $\mathrm{Ar}_{2}$ TBPs by oxidizing metalated $\mathrm{Ar}_{2}$ TCHPs surprisingly turned out unsuccessful. First of all, the metalation itself appeared to be difficult because of the very poor solubility of $\mathbf{4 a - c}$ free bases $\left(\mathrm{H}_{2} \mathrm{Ar}_{2} \mathrm{TCHP}\right)$. For example, prolonged refluxing of $\mathrm{H}_{2} \mathrm{Ar}_{2} \mathrm{TCHPs}$ with $\mathrm{Zn}$ or $\mathrm{Cu}$ salts in common solvents $\left(\mathrm{CHCl}_{3}, \mathrm{CHCl}_{3} / \mathrm{MeOH}, \mathrm{MeCN}\right.$, or DMF) gave only traces of the corresponding metal complexes, while the attempts to insert $\mathrm{Pd}$ in either $\mathrm{DMF}$ or $\mathrm{PhCN}$ simply led to decomposition of the starting porphyrins. Using porphyrin dications $\left(\mathrm{H}_{4} \mathrm{Ar}_{2} \mathrm{TCHP}^{2+}\right)$, which are much more soluble than free bases, improved the metalation yields. In a typical procedure, a mixture containing the dication chloride (or 
trifluoroacetate) and, for example, $\mathrm{Cu}$ or $\mathrm{Zn}$ acetate was brought to reflux in $\mathrm{CHCl}_{3} / \mathrm{MeOH}$ and treated with triethylamine $\left(\mathrm{Et}_{3} \mathrm{~N}\right)$. The free base, formed instantaneously upon the addition of $\mathrm{Et}_{3} \mathrm{~N}$, was metalated prior to aggregation and precipitation. To insert $\mathrm{Pd}$, a similar procedure in benzonitrile was adopted. Metalated $\mathrm{Ar}_{2}$ TCHPs $\left(\mathrm{MAr}_{2} \mathrm{TCHP}\right.$ : M-4, M = Zn, Ni, Cu, Pd) appeared to be much more soluble than the corresponding free bases, especially in $\mathrm{CHCl}_{3}$ and $\mathrm{CH}_{2} \mathrm{Cl}_{2}$.

The second, more serious, problem was encountered during the aromatization step. The protocol developed for the synthesis of MAr ${ }_{4} \mathrm{TBPs}{ }^{7}$ that is, treatment of $\mathrm{MAr}_{2} \mathrm{TCHPs}$ with DDQ in boiling solvents, failed to give $\mathrm{MAr}_{2}$ TBPs. Analysis of the reaction mixtures revealed that aromatization of $\mathrm{MAr}_{2} \mathrm{TCHPs}$ occurred very slowly and never came to completion. $\mathrm{MAr}_{2}$ TCHPs remained largely unaffected even when DDQ was activated by Lewis acids (e.g., $\left.\mathrm{Sc}(\mathrm{OTf})_{3}\right)$. Initially, we speculated that meso-unsubstituted porphyrins undergo oxidative oligomerization, ${ }^{44}$ which could account for the disappearance of both DDQ and the starting metalloporphyrins. However, MALDI MS spectra showed no presence of dimers or trimers. Lower reactivity of $\mathrm{MAr}_{2}$ TCHPs compared to that of either $\mathrm{MAr}_{4}$ TCHPs or MTCHPs remains to be understood.

We further attempted to carry out aromatization of $\mathrm{Ar}_{2} \mathrm{TCHPs}$ without premetalation ${ }^{6 \mathrm{a}}$ - $\mathrm{a}$ strategy employed successfully in the synthesis of meso-unsubstituted TBPs. ${ }^{10}$ Refluxing free bases 4 in toluene with DDQ indeed effected some oxidation, although complete conversions could not be achieved. Therefore, in terms of reactivity, $\mathrm{H}_{2} \mathrm{Ar}_{2}$ TCHPs occupy an intermediate position between $\mathrm{H}_{2} \mathrm{Ar}_{4}$ TCHPs, which are altogether inactive in aromatization, ${ }^{7 \mathrm{a}}$ and mesounsubstituted $\mathrm{H}_{2}$ TCHPs, which can be fully aromatized by DDQ. ${ }^{10}$ Such trend in the reactivity could be a consequence of different basicities of the respective free bases; ${ }^{45}$ that is, more basic $\mathrm{H}_{2} \mathrm{Ar}_{4} \mathrm{TCHPs}$ form dications easier than $\mathrm{H}_{2} \mathrm{TCHPs}$, and dications are inactive in aromatization. Another possible reason for lower reactivity of $\mathrm{H}_{2} \mathrm{Ar}_{2}$ TCHPs is their poor solubility.

The yields of aromatization were greatly improved by using molten naphthalene as a solvent. We have found that molten naphthalene provides an excellent solubilizing medium for poorly soluble porphyrins. However, in this particular reaction, the role of naphthalene could not be fully explained by its solubilizing capacity. No other high-boiling solvent, such as di- or trichlorobenzenes, benzonitrile, nitrobenzole, or durene, was as effective as naphthalene, but at the same time, aromatization in mixtures containing small amounts of naphthalene was in some cases as effective as that in neat naphthalene.

The reaction of $\mathrm{H}_{2} \mathrm{Ar}_{2}$ TCHPs 4a-d with DDQ in molten naphthalene at $180-190{ }^{\circ} \mathrm{C}$ resulted in the full conversion after about $10 \mathrm{~h}$. Unfortunately, MALDI MS analysis revealed the presence of chlorinated $\mathrm{Ar}_{2}$ TBPs as satellite products, and similar results were obtained when $\mathrm{PhCN}$ was used as a solvent for aromatization of Pd complexes (Pd-4). Preparative separation of $\mathrm{Ar}_{2} \mathrm{TBPs}$ from chlorinated $\mathrm{Ar}_{2} \mathrm{TBPs}$ is not feasible since introduction of the chlorine atom (s) into a large porphyrin molecule produces only negligible effect on its chromatographic mobility.

In summary, all attempts to use DDQ for aromatization of $\mathrm{Ar}_{2} \mathrm{TCHPs}$ failed to produce pure $\mathrm{Ar}_{2}$ TBPs. The reactions were either incomplete or suffered from inseparable byproduct.

Aromatization of $\mathrm{Ar}_{2}$ TCHPs Using Tetracyclone-Recently, we have found that 2,3,4,5-tetraphenylcyclopentadienone (tetracyclone) provides an effective alternative to DDQ in aromatization of porphyrins. ${ }^{46}$ Tetracyclone is not a single electron-transfer agent, and therefore, it is incapable of inducing oxidative oligomerization. On the other hand, it does not contain chlorine atoms. Heating of porphyrins 4a-d with tetracyclone in the absence of solvent at $180-230^{\circ}$ (Scheme 5) led to their complete aromatization into $\mathrm{Ar}_{2}$ TBPs. MALDI MS analysis 
revealed only two products in the reaction mixtures (i.e., $\mathrm{Ar}_{2} \mathrm{TBPs} \mathbf{8 a - d}$ ) and the Diels-Alder adducts of the intermediate porphyrins and tetracyclone, which were aromatized by way of $\mathrm{CO}$ extrusion. ${ }^{47}$ The byproduct did not form in large quantities, and $\mathrm{Ar}_{2} \mathrm{TBP}$ could be purified by chromatography.

Porphyrins $\mathbf{8 a}(\mathrm{Ar}=\mathrm{Ph})$ and $\mathbf{8 c}\left(\mathrm{Ar}=4-\mathrm{BrC}_{6} \mathrm{H}_{4}\right)$ were obtained in moderate yields; however, yields of $\mathbf{8 b}$ and $8 \mathbf{d}$ were quite low. Even prolonged heating of the corresponding precursors with tetracyclone resulted in very low conversions. The reason for such dramatic difference in reactivity of $\mathrm{Ar}_{2}$ TCHPs with different substituents in the meso-aryl rings remains unclear.

In conclusion, because of the problems arising at the stage of aromatization, tetrahydroisondole approach as a whole was not regarded as general, although in certain cases, it was a relatively straightforward and cost-effective way to $\mathrm{Ar}_{2} \mathrm{TBPs}$.

\section{Synthesis of $\mathrm{Ar}_{2}$ TBPs via Dihydroisoindole Route}

Recently, we have demonstrated that problems associated with oxidative aromatization in the synthesis of tetrabenzoporphyrins can be effectively overcome by employing 4,7-

dihydroisoindoles. ${ }^{11}$ The latter compounds lead to precursor porphyrins with fewer hydrogen atoms in the pendant rings, facilitating aromatization. Earlier, we have shown that reduction in the number of hydrogens greatly improved the efficiency of aromatization in a similar synthesis of $\mathrm{Ar}_{4}$ TNPs. ${ }^{8}$

4,7-Dihydroisoindoles are studied very scarcely, although the first representative of this class was synthesized over 60 years ago. ${ }^{48}$ An early attempt to approach $\pi$-extended porphyrins via dihydroisoindole - the closest relative of thermodynamically unstable $2 \mathrm{H}$-isoindole - was performed by Fuhrhop et al. in $1985^{49}$ but was unsuccessful. 4,7-Dihydroisoindole was prepared using the classical Paal-Knorr chemistry (Scheme 6A) under conditions which probably harmed the electron-rich pyrrole ring. The apparent instability of 4,7-

dihydroisoindole led researchers to conclude that it was not a useful intermediate in the porphyrin chemistry. It turned out that changing the conditions made it possible to isolate 4,7dihydroisoindole, which proved to be an extremely practical synthon on the way to tetrabenzoporphyrins.

4,7-Dihydroisoindole is accessible in three major steps from readily available tosylacetylene (Scheme 6B). ${ }^{11}$ A modified variant of the Barton-Zard reaction ${ }^{50}$ (Scheme 6B) allows synthesis of 2-alkoxycarbonyl derivatives of 4,7-dihydroisoindole, which are perfectly stable and, in fact, do not differ much in their chemical behavior from well-known and much studied $\beta$-disubstituted 2-alkoxycarbonylpyrroles. Removal of the alkoxycarbonyl group can be accomplished either under acidic (trifluoroacetic acid in $\mathrm{CH}_{2} \mathrm{Cl}_{2}$ ) or basic (reflux with $\mathrm{KOH}$ in ethylene glycol) conditions. In either case, the double bond remains intact.

Similarity in the behavior of 4,7-dihydroisoindole and tetrahydroisoindole enabled us to directly apply methods developed for the tetrahydroisondole pathway to the syntheses originating in 4,7-dihydroisoindole. Both routes shown in Scheme 1 ( $\mathbf{A}$ and $\mathbf{B}$ ) were realized in this pathway, leading to precursor 5,15-diaryloctahydrotetrabenzoporphyrins $\left(\mathrm{Ar}_{2} \mathrm{OHTBPs}\right)$.

Route B (Scheme 7) almost entirely matched its tetrahydroisoindole analogue (see Scheme 3).

Similar to the synthesis depicted in Scheme 3, addition of $\mathrm{Bu}_{4} \mathrm{NCl}$ improved the yield of dipyrromethane 10a. In this case, water scavenging was especially beneficial, as in the absence of $\mathrm{Bu}_{4} \mathrm{NCl}$, tarring occurred, and 10a could be isolated only in a modest yield. Apparently, in 
the presence of water, the double bond of the cyclohexadiene ring interferes with acid-catalyzed condensations.

The formylation reaction, leading to dipyrromethane 12a, gave a somewhat lower yield than the similar reaction in the synthesis of $\mathrm{Ar}_{2}$ TCHPs (Scheme 3). This also could be caused by side reactions, affecting the isolated double bonds in the presence of the strong electrophilic reagent.

In general, route $\mathbf{A}$ (Scheme 1) when applied to the dihydroisoindole pathway appeared to be more reliable than route $\mathbf{B}$, and therefore, it was developed into a general preparative protocol (Scheme 8).

meso-Unsubstituted dipyrromethane 15 was obtained in a good yield from 2ethoxycarbonyl-4,7-dihydroisoindole 9a. Remarkably, the double bond tolerated harsh conditions of the ester cleavage and decarboxylation. Dipyrromethane 15 was introduced into the condensation with aromatic aldehydes under Lindsey conditions to yield the respective $\mathrm{Ar}_{2} \mathrm{OHTBPs}$ 13a-e. These porphyrins were identified in the reaction mixtures by MALDI MS analysis, although they were not isolated and/or characterized. The MALDI spectra revealed only an insignificant degree of scrambling, that is, porphyrins with different numbers of aryl groups. The aromatization was effected directly by changing the solvent to higher-boiling toluene, followed by a short heating with an extra portion of DDQ. Like in the synthesis of $\mathrm{Ar}_{4} \mathrm{TNPs},{ }^{8}$ no metalation was required for aromatization.

Interestingly, in spite of the overall facile reaction, electron-withdrawing groups in meso-aryls, especially the nitro group, decreased the rate of aromatization. Porphyrins 13a and 13d were oxidized almost instantaneously upon bringing their solutions with DDQ to reflux, porphyrin $\mathbf{1 3 c}$ had to be refluxed for $30 \mathrm{~min}$, but 4-nitrophenyl-substituted porphyrin $\mathbf{1 3 b}$ could not be completely aromatized even after prolonged heating. For quantitative aromatization, 13b had to be treated with DDQ in benzonitrile. It is possible that this effect is associated with solubility rather than with electronic factors. In general, contrary to the tetrahydroisoindole pathway, aromatization of the precursors was smooth and no traces of chlorination byproduct were observed.

Overall, the dihydroisoindole pathway is by far the method of choice for the synthesis of $\mathrm{Ar}_{2} \mathrm{TBPs}$, permitting introduction of various functionalities and giving pure target compounds in good yields.

\section{Optical Properties of $\mathrm{Ar}_{2} \mathrm{TBPs}$}

In this section, we only briefly outline the optical properties of $\mathrm{Ar}_{2} \mathrm{TBPs}$, leaving the detailed discussion for a separate account.

The optical absorption and fluorescence spectra of porphyrin 8a are shown in Figure 1A. The optical absorption spectra of free base $8 \mathbf{a}(\mathrm{A})$ are strikingly similar to those of mesounsubstituted $\mathrm{H}_{2}$ TBPs, ${ }^{14}$ showing a well-resolved vibronic structure in the Q-band region and a significant $\left(750 \mathrm{~cm}^{-1}\right)$ splitting of the $\mathrm{B}$ (Soret) band. This feature is typically attributed to a strong mixing of the $\mathrm{Q}$ and $\mathrm{B}$ states and to an increase in the oscillator strengths of the Q-bands in TBPs compared to regular nonextended porphyrins. ${ }^{14 a, 51}$ The fluorescence of $8 \mathbf{a}$ exhibits a sharp band $\left(\lambda_{\max }=670 \mathrm{~nm}\right)$, characterized by a very small Stokes shift (only $2 \mathrm{~nm}$ ) and a very high for porphyrins quantum yield $\left(\varphi_{\mathrm{fl}}=0.38\right)$, pointing toward rigid planar structure, similar to that of meso-unsubstituted $\mathrm{H}_{2}$ TBP. ${ }^{15}$

The Pd complex of 8a, prepared by refluxing the free base with $\mathrm{PdCl}_{2}$ in benzonitrile, exhibits spectral properties (Figure 1B) close to those of meso-unsubstituted PdTBPs. ${ }^{2 a}, 10,16 \mathrm{~b}, 52 \mathrm{An}$ 
unusual feature of Pd-8a is the slight splitting of the Q-band $\left(\lambda_{\max }=615 \mathrm{~nm}\right)$ and a shoulder of the main band in the phosphorescence spectrum $\left(\lambda_{\max }=796 \mathrm{~nm}\right)$. The latter property is unique for Pd-8a and probably for other $\mathrm{PdAr}_{2}$ TBPs since meso-unsubstituted PdTBPs and Pd meso-tetraaryl-TBPs exhibit quite symmetrical phosphorescent bands, accompanied by small vibrational satellites. The phosphorescence lifetime of Pd-8a, measured in Ar-purged dimethylacetamide solution, was found to be $490 \mu \mathrm{s}$, and on air, the phosphorescence was completely quenched. The phosphorescence quantum yield in the absence of oxygen was 0.19 , which is quite high compared to the other Pd tetrabenzoporphyrins. ${ }^{7,10}$ These characteristics suggest suitability of $\mathrm{PdAr}_{2}$ TBPs for oxygen sensing and imaging ${ }^{2}$ as well as for PDT. ${ }^{4}$

Conjugated porphyrin-based molecules are currently under intensive scrutiny as nonlinear optical materials. ${ }^{19 a, 53}$ Tetrabenzoporphyrins in particular have been investigated as potential two-photon probes for biomedical imaging. $2 \mathrm{~g}$ We have determined that, upon irradiation with 110 fs pulses from a Ti:sapphire laser (76 MHz rep. rate), solutions of 8a exhibit strong fluorescence, whose intensity was proportional to the square of the excitation flux, confirming that the two-photon absorption was the main process underlying the emission from the singlet excited state (Figure 2).

The two-photon absorption cross-section $\left(\sigma_{2}\right)$ of $\mathbf{8 a}$, determined by the relative fluorescence method versus Rhodamine B in methanol $\left(\sigma_{2}=210 \mathrm{GM},{ }^{54} \lambda_{\mathrm{ex}}=840 \mathrm{~nm}, \varphi_{\mathrm{fl}}=0.5^{55}\right)$, was found to be $28 \mathrm{GM}\left(1 \mathrm{GM}=10^{-50} \mathrm{~cm}^{4} \mathrm{~s}\right.$ photon $\left.{ }^{-1}\right)$, which is several times higher than the values reported for regular nonextended porphyrins. 56 This value is consistent with other measurements performed on tetrabenzoporphyrins, ${ }^{57}$ confirming that $\pi$-extension has a profound effect on nonlinear absorption of tetrapyrroles.

In conclusion, $\mathrm{Ar}_{2} \mathrm{TBPs}$ possess an array of useful optical properties. They combine strong emissivity of the planar TBP system and enhanced two-photon absorption cross-sections with the possibility of derivatization via functional substituents in the meso-aryl rings. These characteristics suggest a wide array of utilities, including biomedical imaging, sensing, and nonlinear optical applications. The developed method of synthesis provides a general route to $\mathrm{Ar}_{2}$ TBPs with various substituents, facilitating engagement of these molecules into applied research.

\section{Experimental Part}

For general description of methods, see Supporting Information. Tetrahydroisoindole esters $\mathbf{1 a}$ and $\mathbf{1} \mathbf{b}^{39}$ and dihydroisoindole $9 \mathbf{b}^{11}$ were synthesized as described previously.

\section{Bis(3-ethoxycarbonyl-4,5,6,7-tetrahydro-2H-isoindolyl)methane (2)}

A mixture of 2-ethoxycarbonyl-4,5,6,7-tetrahydro- $2 H$-isoindole $1 \mathrm{a}(1.93 \mathrm{~g}, 10 \mathrm{mmol})$, dimethoxymethane $(0.38 \mathrm{~g}, 5 \mathrm{mmol})$, and $p$-toluenesulfonic acid $(0.095 \mathrm{~g}, 0.5 \mathrm{mmol})$ was dissolved in acetic acid $(50 \mathrm{~mL})$. The mixture was stirred at room temperature for $24 \mathrm{~h}$ and poured into cold water $(200 \mathrm{~mL})$. The precipitate formed, and it was collected by filtration, dried in vacuum over $\mathrm{P}_{2} \mathrm{O}_{5}$, and recrystallized from ethanol: yield $1.79 \mathrm{~g}(90 \%)$, white powder, $\mathrm{mp} 210-211{ }^{\circ} \mathrm{C} ;{ }^{1} \mathrm{H}$ NMR (CDCl $3-d_{6}$-DMSO) $\delta 10.86(\mathrm{br} \mathrm{s}, 2 \mathrm{H}), 4.15(\mathrm{q}, J=7.11 \mathrm{~Hz}, 4 \mathrm{H})$, $3.60(\mathrm{~s}, 2 \mathrm{H}), 2.62(\mathrm{~m}, 4 \mathrm{H}), 2.38(\mathrm{~m}, 4 \mathrm{H}), 1.60(\mathrm{~m}, 8 \mathrm{H}), 1.23(\mathrm{t}, J=7.11 \mathrm{~Hz}, 6 \mathrm{H}) ;{ }^{13} \mathrm{C}$ NMR $\left(\mathrm{CDCl}_{3}-d_{6}\right.$-DMSO) $\delta 161.2,129.7,127.5,117.3,115.7,58.7,22.9,22.8,22.8,21.2,20.9,14.2$. Anal. Calcd for $\mathrm{C}_{23} \mathrm{H}_{30} \mathrm{~N}_{2} \mathrm{O}_{4}$ (398.49): C, 69.32; H, 7.59; N, 7.03. Found: C, 69.40; H, 7.50; N, 7.31 . 
Bis(4,5,6,7-tetrahydro-2 $\mathrm{H}$-isoindolyl)methane (3) and Bis(4,7-dihydro-2H-isoindolyl)methane (15)

A mixture of the corresponding dipyrromethane 2 or 14 (3 mmol), KOH (18 mmol, $1.00 \mathrm{~g}$ ) and ethylene glycol $(30 \mathrm{~mL})$ was refluxed under argon for $1 \mathrm{~h}$. The mixture was cooled to room temperature, diluted with $\mathrm{CH}_{2} \mathrm{Cl}_{2}(50 \mathrm{~mL})$, and washed with water $(5 \times 100 \mathrm{~mL})$ and saturated brine $(20 \mathrm{~mL})$. The mixture was concentrated by evaporation in vacuum, passed through a short silica gel column ( $5 \mathrm{~cm}$, eluent: $\mathrm{CH}_{2} \mathrm{Cl}_{2}$ ), and evaporated in vacuum to dryness. The obtained dipyrromethane was either immediately used in the porphyrin synthesis without further purification or stored at $-18{ }^{\circ} \mathrm{C}$.

\section{$\mathrm{Ar}_{2}$ TCHPs (4a-d) via Route A (Scheme 2)}

Dipyrromethane 3 ( $1 \mathrm{mmol}, 0.25 \mathrm{~g})$ and aromatic aldehyde $(1 \mathrm{mmol})$ were dissolved in $\mathrm{CH}_{2} \mathrm{Cl}_{2}(60 \mathrm{~mL})$ and freshly distilled over $\mathrm{CaH}_{2}$. The mixture was stirred for 10 min under Ar, and trifluoroacetic acid (TFA) $(0.135 \mathrm{mmol}, 0.015 \mathrm{~g})$ was added and the mixture stirred for 6 h. A solution of DDQ $(1.5 \mathrm{mmol}, 0.34 \mathrm{~g})$ in toluene $(20 \mathrm{~mL})$ was added, and the mixture was stirred for an additional $2 \mathrm{~h}$, evaporated in vacuum, and chromatographed on silica gel (eluent: $\mathrm{CH}_{2} \mathrm{Cl}_{2} / \mathrm{Et}_{3} \mathrm{~N}, 100: 1 \mathrm{v} / \mathrm{v}$ ). Fractions containing the desired porphyrins (selected by UV-vis spectroscopy) were combined, evaporated in vacuum to dryness, treated with TFA $(0.02 \mathrm{~mL})$, dried in vacuum, and precipitated from $\mathrm{CH}_{2} \mathrm{Cl}_{2}$ solution as free bases upon addition of diethyl ether.

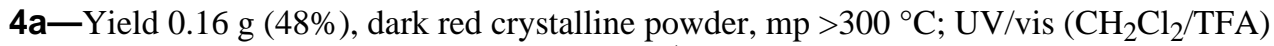
$\lambda_{\max }(\log \epsilon) 426$ (5.62), 566 (4.28), 610 (3.93); ${ }^{1} \mathrm{H}$ NMR ( $\left.\mathrm{CDCl}_{3} / \mathrm{TFA}\right) \delta 10.12(\mathrm{~s}, 2 \mathrm{H}), 8.22$ $(\mathrm{m}, 4 \mathrm{H}), 7.88(\mathrm{~m}, 6 \mathrm{H}), 3.78(\mathrm{~m}, 8 \mathrm{H}), 2.66(\mathrm{~m}, 8 \mathrm{H}), 2.31(\mathrm{~m}, 8 \mathrm{H}), 1.73(\mathrm{~m}, 8 \mathrm{H}),-2.14(\mathrm{br} \mathrm{s}$, $4 \mathrm{H}) ;{ }^{13} \mathrm{C}$ NMR $\left(\mathrm{CDCl}_{3} / \mathrm{TFA}\right) \delta 142.6,140.6,139.1,138.5,138.2,134.9,130.0,128.7,119.3$, 96.7, 25.2, 23.6, 22.9, 22.1; ESI HRMS $m / z$ 679.3823; calcd for $\mathrm{C}_{48} \mathrm{H}_{47} \mathrm{~N}_{4}\left(\mathrm{MH}^{+}\right) 679.3801$.

4b-Yield $0.049 \mathrm{~g}(13 \%)$, dark red crystalline powder, $\mathrm{mp}>300^{\circ} \mathrm{C}$; UV/vis $\left(\mathrm{CH}_{2} \mathrm{Cl}_{2} / \mathrm{TFA}\right)$ $\lambda_{\max }(\log \epsilon) 432$ (5.47), 568 (4.28), 614 (3.91); ${ }^{1} \mathrm{H}$ NMR (CDCl $\left.3 / \mathrm{TFA}\right) \delta 10.18(\mathrm{~s}, 2 \mathrm{H}), 8.77$ (m, 4H), $8.49(\mathrm{~m}, 4 \mathrm{H}), 3.79(\mathrm{~m}, 8 \mathrm{H}), 2.63(\mathrm{~m}, 8 \mathrm{H}), 2.33(\mathrm{~m}, 8 \mathrm{H}), 1.76(\mathrm{~m}, 8 \mathrm{H}),-1.94(\mathrm{br} \mathrm{s}$, $4 \mathrm{H}) ;{ }^{13} \mathrm{C} \mathrm{NMR}\left(\mathrm{CDCl}_{3}\right.$ /TFA) $\delta 148.9,143.6,141.4,139.8,137.7,135.8,123.7,116.5,97.7$, 25.7, 23.6, 22.8, 21.9; MALDI-TOF MS $m / z$ 768.96; calcd for $\mathrm{C}_{48} \mathrm{H}_{45} \mathrm{~N}_{6} \mathrm{O}_{4}\left(\mathrm{MH}^{+}\right) 769.35$.

4c-Yield $0.11 \mathrm{~g}(27 \%)$, dark red crystalline powder, $\mathrm{mp}>300^{\circ} \mathrm{C}$; UV/vis $\left(\mathrm{CH}_{2} \mathrm{Cl}_{2} / \mathrm{TFA}\right)$ $\lambda_{\max }(\log \epsilon) 428$ (5.61), 562 (4.26), $612(3.83) ;{ }^{1} \mathrm{H} \mathrm{NMR}\left(\mathrm{CDCl}_{3} / \mathrm{TFA}\right) \delta 10.14$ (s, 2H), 8.12 $(\mathrm{m}, 4 \mathrm{H}), 8.05(\mathrm{~m}, 4 \mathrm{H}), 3.78(\mathrm{~m}, 8 \mathrm{H}), 2.70(\mathrm{~m}, 8 \mathrm{H}), 2.33(\mathrm{~m}, 8 \mathrm{H}), 1.77(\mathrm{~m}, 8 \mathrm{H}),-2.24(\mathrm{br} \mathrm{s}$, $4 \mathrm{H}) ;{ }^{13} \mathrm{C}$ NMR $\left(\mathrm{CDCl}_{3} / \mathrm{TFA}\right) \delta 142.3,140.9,139.3,138.1,137.0,136.3,132.1,125.3,117.7$, 97.0, 25.5, 23.6, 22.9, 22.0; MALDI-TOF MS $m / z$ 836.77; calcd for $\mathrm{C}_{48} \mathrm{H}_{45} \mathrm{Br}_{2} \mathrm{~N}_{4}\left(\mathrm{MH}^{+}\right)$ 837.20 .

4d-Yield $0.24 \mathrm{~g}(60 \%)$, dark red crystalline powder, $\mathrm{mp}>300^{\circ} \mathrm{C}$; UV/vis $\left(\mathrm{CH}_{2} \mathrm{Cl}_{2} / \mathrm{TFA}\right)$ $\lambda_{\max }(\log \epsilon) 428$ (5.59), 568 (4.23), 612 (3.82); ${ }^{1} \mathrm{H}$ NMR ( $\left.\mathrm{CDCl}_{3} / \mathrm{TFA}\right) \delta 10.18$ (s, 2H), 8.58 $(\mathrm{m}, 2 \mathrm{H}), 8.35(\mathrm{~m}, 2 \mathrm{H}), 4.15(\mathrm{~s}, 3 \mathrm{H}), 3.79(\mathrm{~m}, 8 \mathrm{H}), 2.65(\mathrm{~m}, 8 \mathrm{H}), 2.32(\mathrm{~m}, 8 \mathrm{H}), 1.74(\mathrm{~m}, 8 \mathrm{H})$, -2.37 (br s, $4 \mathrm{H}) ;{ }^{13} \mathrm{C}$ NMR (CDCl 3 -TFA) $\delta 167.1,142.0,141.7,140.9,139.6,138.3,135.0$, 131.3, 129.8, 118.0, 97.2, 52.8, 25.4, 23.5, 22.8, 21.9; ESI HRMS $\mathrm{m} / z$ 795.3878; calcd for $\mathrm{C}_{52} \mathrm{H}_{51} \mathrm{~N}_{4} \mathrm{O}_{4}\left(\mathrm{MH}^{+}\right)$795.3905; MALDI-TOF MS m/z 795.33; calcd for $\mathrm{C}_{52} \mathrm{H}_{51} \mathrm{~N}_{4} \mathrm{O}_{4}\left(\mathrm{MH}^{+}\right)$ 795.39 .

\section{Arylbis(3-tert-butoxycarbonyl-4,5,6,7-tetrahydro-2H-isoindolyl)-methanes (5a-c)}

$p$-Toluenesulfonic acid $(0.25 \mathrm{mmol}, 0.048 \mathrm{~g})$ and $n$-tetrabutylammonium chloride $(0.1 \mathrm{mmol}$, $0.028 \mathrm{~g}$ ) were added to a solution of 2-tert-butoxycarbonyl-4,5,6,7-tetrahydro- $2 \mathrm{H}$-isoindole 
1b $(5 \mathrm{mmol}, 1.105 \mathrm{~g})$ and the corresponding aldehyde $(2.5 \mathrm{mmol})$ in $\mathrm{CHCl}_{3}(50 \mathrm{~mL})$. The reaction mixture was stirred at room temperature under argon for $12 \mathrm{~h}$, washed by $\mathrm{NaHCO}_{3}$ ( $10 \%$ aqueous solution, $20 \mathrm{~mL}$ ) and saturated brine $(20 \mathrm{~mL})$, and dried over $\mathrm{Na}_{2} \mathrm{SO}_{4}$. The solution was evaporated to dryness, and the residue was purified by column chromatography on silica gel (eluent: petroleum ether/ethyl acetate, 5:1). The fractions containing the target dipyrromethane were identified by TLC (silica gel plates, eluent: petroleum ether/ethyl acetate, 5:1). Upon heating to $150{ }^{\circ} \mathrm{C}$ the spots with $R_{f} 0.85-0.9$ turned red. These fractions were combined and evaporated to dryness.

5a-Yield $1.26 \mathrm{~g}$ (95\%), orange amorphous solid; ${ }^{1} \mathrm{H} \mathrm{NMR}\left(\mathrm{CDCl}_{3}\right) \delta 8.27$ (br s, $\left.2 \mathrm{H}\right)$, 7.36-7.26 (m, 3H), $7.12(\mathrm{~m}, 2 \mathrm{H}), 5.39(\mathrm{~s}, 1 \mathrm{H}), 2.78(\mathrm{~m}, 4 \mathrm{H}), 2.17(\mathrm{~m}, 4 \mathrm{H}), 1.69(\mathrm{~m}, 8 \mathrm{H}), 1.54$ $(\mathrm{s}, 18 \mathrm{H}) ;{ }^{13} \mathrm{C} \mathrm{NMR}\left(\mathrm{CDCl}_{3}\right) \delta 161.2,138.8,129.9,129.0,128.2,127.4,119.4,117.8,80.1,41$. 4, 28.5, 23.3, 23.2, 23.1, 21.2. Anal. Calcd for $\mathrm{C}_{33} \mathrm{H}_{42} \mathrm{~N}_{2} \mathrm{O}_{4}$ (530.70): C, 74.69; H, 7.98; N, 5.28. Found: C, 74.93; H, 8.16; N, 4.94.

5b-Yield $1.22 \mathrm{~g}(85 \%)$, yellow amorphous solid; ${ }^{1} \mathrm{H}$ NMR $\left(\mathrm{CDCl}_{3}\right) \delta 8.52$ (br s, $\left.2 \mathrm{H}\right), 8.09$ $(\mathrm{m}, 2 \mathrm{H}), 7.22(\mathrm{~m}, 2 \mathrm{H}), 5.47(\mathrm{~s}, 1 \mathrm{H}), 2.74(\mathrm{~m}, 4 \mathrm{H}), 2.13(\mathrm{~m}, 4 \mathrm{H}), 1.65(\mathrm{~m}, 8 \mathrm{H}), 1.50(\mathrm{~s}$, $18 \mathrm{H}) ;{ }^{13} \mathrm{C} \mathrm{NMR}\left(\mathrm{CDCl}_{3}\right) \delta 161.2,147.1,146.7,129.2,128.3,128.1,124.1,119.9,118.7,80.6$, 40.9, 28.5, 23.3, 23.1, 21.4. Anal. Calcd for $\mathrm{C}_{33} \mathrm{H}_{41} \mathrm{~N}_{3} \mathrm{O}_{6}$ (575.70): C, 68.85; H, 7.18; N, 7.30. Found: C, 68.41; H, 7.47; N, 7.02.

5c-Yield $1.44 \mathrm{~g}(95 \%)$, orange amorphous solid; ${ }^{1} \mathrm{H}$ NMR $\left(\mathrm{CDCl}_{3}\right) \delta 8.30(\mathrm{~s}, 2 \mathrm{H}), 7.41(\mathrm{~m}$, $2 \mathrm{H}), 6.95(\mathrm{~m}, 2 \mathrm{H}), 5.32(\mathrm{~s}, 1 \mathrm{H}), 2.74(\mathrm{~m}, 4 \mathrm{H}), 2.13(\mathrm{~m}, 4 \mathrm{H}), 1.66(\mathrm{~m}, 8 \mathrm{H}), 1.51(\mathrm{~s}, 18 \mathrm{H}) ;{ }^{13} \mathrm{C}$ $\operatorname{NMR}\left(\mathrm{CDCl}_{3}\right) \delta 161.2,138.0,132.1,130.0,129.2,128.2,121.3,119.5,118.1,80.2,40.5,28.5$, 23.3, 23.1, 23.1, 21.3. Anal. Calcd for $\mathrm{C}_{33} \mathrm{H}_{41} \mathrm{BrN}_{2} \mathrm{O}_{4}$ (609.59): C, 65.02; H, 6.78; $\mathrm{Br}, 13.11$; $\mathrm{N}$, 4.60. Found: C, 65.42; H, 6.77; N, 4.21.

\section{Arylbis(3-formyl-4,5,6,7-tetrahydro-2H-isoindolyl)methanes (7a-c)}

Dipyrromethanes 5a-c ( $2 \mathrm{mmol})$ were dissolved in TFA $(20 \mathrm{~mL})$ under argon. The solution was stirred for $5 \mathrm{~min}$ and cooled to $0{ }^{\circ} \mathrm{C}$ on an ice bath. Trimethoxymethane $(20 \mathrm{mmol}, 2.1 \mathrm{~g}$ ) was added dropwise to the mixture. The mixture was stirred for $15 \mathrm{~min}$ at room temperature, diluted with $\mathrm{CH}_{2} \mathrm{Cl}_{2}(50 \mathrm{~mL})$, washed with saturated aqueous $\mathrm{NaHCO}_{3}(2 \times 20 \mathrm{~mL})$ and saturated brine $(20 \mathrm{~mL})$, and dried over $\mathrm{Na}_{2} \mathrm{SO}_{4}$. The resulting solution was evaporated to dryness, and the remaining solid was chromatographed on silica gel (eluent: $\mathrm{CH}_{2} \mathrm{Cl}_{2} / \mathrm{MeOH}$ ). Compounds 7a-c could not be recrystallized due to their rather poor solubility, and therefore, they did not give satisfactory elemental analyses.

7a-Yield $0.46 \mathrm{~g}(60 \%)$, gray powder, $\mathrm{mp}>300{ }^{\circ} \mathrm{C} ;{ }^{1} \mathrm{H}$ NMR $\left(\mathrm{CDCl}_{3}\right) \delta 9.85(\mathrm{br} \mathrm{s}, 2 \mathrm{H}), 9.35$ $(\mathrm{s}, 2 \mathrm{H}), 7.30(\mathrm{~m}, 3 \mathrm{H}), 7.11(\mathrm{~m}, 2 \mathrm{H}), 5.50(\mathrm{~s}, 1 \mathrm{H}), 2.83(\mathrm{~m}, 4 \mathrm{H}), 2.30(\mathrm{~m}, 4 \mathrm{H}), 1.77(\mathrm{~m}$, $8 \mathrm{H}) ;{ }^{13} \mathrm{C} \mathrm{NMR}\left(\mathrm{CDCl}_{3}\right) \delta 176.2,138.1,129.0,128.6,128.2,127.5,127.5,120.9,40.4,23.1$, 22.7, 21.0, 20.9.

7b-Yield $0.69 \mathrm{~g}(80 \%)$, gray powder, $\mathrm{mp}>300{ }^{\circ} \mathrm{C} ;{ }^{1} \mathrm{H}$ NMR $\left(\mathrm{CDCl}_{3}-d_{6}\right.$-DMSO) $\delta 11.31$ (s, $2 \mathrm{H}), 9.38(\mathrm{~s}, 2 \mathrm{H}), 8.02(\mathrm{~m}, 2 \mathrm{H}), 7.16(\mathrm{~m}, 2 \mathrm{H}), 5.50(\mathrm{~s}, 1 \mathrm{H}), 2.74(\mathrm{~m}, 4 \mathrm{H}), 2.41(\mathrm{~m}, 4 \mathrm{H}), 1.70$ $(\mathrm{m}, 8 \mathrm{H}) ;{ }^{13} \mathrm{C}$ NMR $\left(d_{6}\right.$-DMSO) $\delta 176.8,147.3,146.4,133.7,129.4,127.7,123.6,120.3,30.3$, $22.8,22.3,20.5$.

7c-Yield $0.56 \mathrm{~g}(60 \%)$, gray powder, $\mathrm{mp}>300{ }^{\circ} \mathrm{C} ;{ }^{1} \mathrm{H}$ NMR $\left(d_{6}\right.$-DMSO) $\delta 11.39(\mathrm{br} \mathrm{s}, 2 \mathrm{H})$, $9.43(\mathrm{~s}, 2 \mathrm{H}), 7.51(\mathrm{~m}, 2 \mathrm{H}), 6.99(\mathrm{~m}, 2 \mathrm{H}), 5.56(\mathrm{~s}, 1 \mathrm{H}), 2.75(\mathrm{~m}, 4 \mathrm{H}), 2.40-2.18(\mathrm{~m}, 4 \mathrm{H}), 1.64$ $(\mathrm{m}, 8 \mathrm{H})$; satisfactory ${ }^{13} \mathrm{C}$ NMR spectrum could not be obtained because of the very low solubility. 


\section{$\mathrm{Ar}_{2}$ TCHPs (4a-d) via Route B (Scheme 3)}

Aryldipyrromethanes 5a-c $(1 \mathrm{mmol})$ were dissolved in TFA $(20 \mathrm{~mL})$ under argon. The solution was stirred for $5 \mathrm{~min}$, diluted with $\mathrm{CH}_{2} \mathrm{Cl}_{2}(50 \mathrm{~mL})$, and added to a solution of the respective diformyldipyrromethane $\mathbf{7 a - c}$ in $\mathrm{CH}_{2} \mathrm{Cl}_{2}(45 \mathrm{~mL})$. The resulting mixture was stirred at room temperature for $4 \mathrm{~h}$, treated with DDQ $(1.5 \mathrm{mmol}, 0.34 \mathrm{~g})$, and stirred for an additional $2 \mathrm{~h}$. The workup and the isolation of the target compounds were performed as in route $\mathbf{A}$. Yields: 4a $0.07 \mathrm{~g} \mathrm{(20 \% ),} \mathrm{4b} 0.10 \mathrm{~g}(26 \%), 4 \mathbf{c} 0.07 \mathrm{~g}(17 \%)$.

\section{Metal Complexes of Porphyrins 4a-c}

Porphyrins 4a-c $(0.1 \mathrm{mmol})$ were dissolved in TFA $(0.2 \mathrm{~mL})$, and the solution was evaporated to dryness. The remaining solid was dissolved in $\mathrm{CH}_{2} \mathrm{Cl}_{2}(50 \mathrm{~mL})$, and a solution of $\mathrm{Cu}$ or $\mathrm{Zn}$ acetate in $\mathrm{MeOH}(5 \mathrm{~mL})$ was added. The mixture was stirred for $5 \mathrm{~min}$, and $\mathrm{Et}_{3} \mathrm{~N}(0.05 \mathrm{~mL})$ was added in one portion by a pipet. The mixture was stirred for an additional $5 \mathrm{~min}$, transferred to a separatory funnel, washed with water $(20 \mathrm{~mL})$ and brine $(20 \mathrm{~mL})$, and dried over $\mathrm{Na}_{2} \mathrm{SO}_{4}$. The solution was concentrated in vacuum to about $10 \mathrm{~mL}$, and the resulting metal complex was precipitated by ether. The crystalline solid was filtered off, washed with ether, and dried. The purity of the metal complex was assessed by MALDI MS analysis and UV-vis spectroscopy.

\section{Aromatization of Porphyrins $4 \mathrm{a}$ and $4 \mathrm{c}$ by 2,3,4,5-Tetraphenylcyclopentadienone (Tetracyclone) (Scheme 5)}

A mixture of the porphyrin (4a or $\mathbf{4 c})(0.1 \mathrm{mmol})$ and tetracyclone $(2.6 \mathrm{mmol}, 1 \mathrm{~g})$ was placed into a high-pressure glass tube, which was purged with Ar and closed with a PTFE screw cap. The mixture was heated to at $230^{\circ} \mathrm{C}$ and kept under stirring for $3 \mathrm{~h}$. After cooling to the room temperature, the mixture was dissolved in $\mathrm{CH}_{2} \mathrm{Cl}_{2}$ and chromatographed on silica gel (eluent: $\mathrm{CH}_{2} \mathrm{Cl}_{2}$ ). Further purification of porphyrins $8 \mathbf{a}$ and $\mathbf{8 c}$ was achieved by recrystallization from $\mathrm{CH}_{2} \mathrm{Cl}_{2} /$ ether. Yields: $8 \mathbf{a} 0.036 \mathrm{~g}(55 \%), 8 \mathrm{c} 0.037 \mathrm{~g}(45 \%)$. See the analytical data for porphyrins $8 \mathbf{a}$ and $8 \mathbf{c}$ below.

\section{2-Ethoxycarbonyl-4,7-dihydro-2H-isoindole (9a)}

9a was obtained by the method used previously for the synthesis of tert-butyl ester $9 \mathbf{b}:{ }^{11}$ yield $73 \%$, white powder, $\mathrm{mp} 87-88{ }^{\circ} \mathrm{C} ;{ }^{1} \mathrm{H}$ NMR $\left(\mathrm{CDCl}_{3}\right) \delta 8.97(\mathrm{br} \mathrm{s}, 1 \mathrm{H}), 6.70(\mathrm{~m}, 1 \mathrm{H}), 5.87(\mathrm{~m}$, $2 \mathrm{H}), 4.30(\mathrm{q}, J=7.12 \mathrm{~Hz}, 2 \mathrm{H}), 3.43(\mathrm{~m}, 2 \mathrm{H}), 3.22(\mathrm{~m}, 2 \mathrm{H}), 1.35(\mathrm{t}, J=7.12 \mathrm{~Hz}, 3 \mathrm{H}) ;{ }^{13} \mathrm{C}$ NMR $\left(\mathrm{CDCl}_{3}\right) \delta 161.6,124.9,124.4,123.8,118.9,117.5,59.8,24.0,22.3,14.5$. Anal. Calcd for $\mathrm{C}_{11} \mathrm{H}_{13} \mathrm{NO}_{2}$ (191.23): C, 69.09; H, 6.85; N, 7.32. Found: C, 68.77; H, 7.00; N, 7.03.

\section{Bis(3-ethoxycarbonyl-4,7-dihydro-2H-isoindolyl)methane (14)}

Compound 14 was obtained from $9 \mathrm{a}$ by the same procedure as used in the synthesis of dipyrromethane 2: yield $1.81 \mathrm{~g}(92 \%)$, white powder, $\mathrm{mp} 269-270{ }^{\circ} \mathrm{C} ;{ }^{1} \mathrm{H} \mathrm{NMR}\left(\mathrm{CDCl}_{3}-d_{6^{-}}\right.$ DMSO) $\delta 11.21(\mathrm{br} \mathrm{s}, 2 \mathrm{H}), 5.76(\mathrm{~m}, 4 \mathrm{H}), 4.18(\mathrm{q}, J=7.08 \mathrm{~Hz}, 4 \mathrm{H}), 3.71(\mathrm{~s}, 2 \mathrm{H}), 3.25(\mathrm{~m}, 4 \mathrm{H}$, overlapped with solvent), $3.00(\mathrm{~m}, 4 \mathrm{H}), 1.26(\mathrm{t}, J=7.08 \mathrm{~Hz}, 4 \mathrm{H}) ;{ }^{13} \mathrm{C} \mathrm{NMR}\left(\mathrm{CDCl}_{3}-d_{6}\right.$-DMSO) $\delta$ 160.7, 129.3, 124.0, 123.9, 123.1, 115.3, 114.2, 58.6, 23.8, 21.6, 21.4, 14.2. Anal. Calcd for $\mathrm{C}_{23} \mathrm{H}_{26} \mathrm{~N}_{2} \mathrm{O}_{4}$ (394.46): C, 70.03; H, 6.64; N, 7.10. Found: $\mathrm{C}, 69.88 ; \mathrm{H}, 6.34 ; \mathrm{N}, 6.85$.

\section{$\mathrm{Ar}_{2}$ TBPs 8a-d via Dihydroisoindole Pathway (Scheme 8)}

Freshly prepared dipyrromethane 15 (1 mmol, $0.25 \mathrm{~g})$ was dissolved in $\mathrm{CH}_{2} \mathrm{Cl}_{2}(60 \mathrm{~mL})$, distilled over $\mathrm{CaH}_{2}$, and the aromatic aldehyde $(1 \mathrm{mmol})$ was added to this solution. The mixture was stirred under $\mathrm{Ar}$ at room temperature for $10 \mathrm{~min}$ and treated with TFA $(0.135$ mmol, $0.015 \mathrm{~g}$ ). The reaction mixture was stirred at room temperature for $4 \mathrm{~h}$, treated with DDQ $(1.5 \mathrm{mmol}, 0.34 \mathrm{~g})$ in toluene $(20 \mathrm{~mL})$, and stirred for an additional $2 \mathrm{~h}$. The solution 
was evaporated to dryness, and the residue was dissolved in either toluene $(30 \mathrm{~mL}, \mathbf{8 a}, \mathbf{c}, \mathbf{d})$ or in benzonitrile $(30 \mathrm{~mL}, \mathbf{8 b})$. DDQ $(2 \mathrm{mmol}, 0.45 \mathrm{~g})$ was added, and the mixture was refluxed for 5-30 min under Ar. The reaction was monitored by UV-vis spectroscopy. The solvent was removed in vacuum, and the residue was purified by chromatography on silica gel (eluent: $\mathrm{CH}_{2} \mathrm{Cl}_{2}$ ). Emerald green fractions were collected, combined, and evaporated to dryness. The residue was treated with TFA $(0.01 \mathrm{~mL})$ and dried in vacuum. The porphyrins were additionally purified by reprecipitation from $\mathrm{CH}_{2} \mathrm{Cl}_{2}$ solutions by ether. Porphyrins 8a-e were isolated as free bases.

8a-Yield $0.073 \mathrm{~g} \mathrm{(22 \% ),} \mathrm{the} \mathrm{material} \mathrm{was} \mathrm{characterized} \mathrm{in} \mathrm{ref}{ }^{11}$.

8b-Yield $0.056 \mathrm{~g}(15 \%)$, green powder, $\mathrm{mp}>300{ }^{\circ} \mathrm{C}$; UV/vis $\left(\mathrm{CH}_{2} \mathrm{Cl}_{2} / \mathrm{TFA}\right) \lambda_{\max }(\log \epsilon)$ $\left(\mathrm{CH}_{2} \mathrm{Cl}_{2}\right)$ as free base 394 (4.92), 420 (5.70), 436 (5.62), 570 (4.64), 612 (4.99), 666 (4.75); ${ }^{1} \mathrm{H} \mathrm{NMR}\left(\mathrm{CDCl}_{3} / \mathrm{TFA}\right) \delta 11.01(\mathrm{~s}, 2 \mathrm{H}), 9.36(\mathrm{~d}, J=7.96 \mathrm{~Hz}, 4 \mathrm{H}), 8.32(\mathrm{~m}, 4 \mathrm{H}), 8.24$ $(\mathrm{m}, 4 \mathrm{H}), 8.20(\mathrm{~m}, 4 \mathrm{H}), 7.94(\mathrm{~m}, 4 \mathrm{H}), 7.69(\mathrm{~d}, J=8.34 \mathrm{~Hz}, 4 \mathrm{H}),-0.35(\mathrm{br} \mathrm{s}, 4 \mathrm{H}) ;{ }^{13} \mathrm{C}$ NMR $\left(\mathrm{CDCl}_{3} / \mathrm{TFA}\right) \delta 139.9,139.0,137.3,136.0,133.4,132.9,131.9,130.8,130.6,125.9,125.2$, 123.6, 114.9, 92.4; LDI-TOF MS $m / z$ 752.17; calcd for $\mathrm{C}_{48} \mathrm{H}_{28} \mathrm{~N}_{6} \mathrm{O}_{4}\left(\mathrm{M}^{+}\right)$752.22. Anal. Calcd for $\mathrm{C}_{48} \mathrm{H}_{28} \mathrm{~N}_{6} \mathrm{O}_{4} \cdot 0.33 \mathrm{Et}_{2} \mathrm{O}: \mathrm{C}, 76.21 ; \mathrm{H}, 4.06 ; \mathrm{N}, 10.81$. Found: $\mathrm{C}, 76.07 ; \mathrm{H}, 4.20 ; \mathrm{N}, 10.73$.

8c-Yield $0.041 \mathrm{~g}(10 \%)$, green powder, $\mathrm{mp}>300{ }^{\circ} \mathrm{C}$; $\mathrm{UV} /$ vis $\left(\mathrm{CH}_{2} \mathrm{Cl}_{2} / \mathrm{TFA}\right) \lambda_{\max }(\log \epsilon)$ as dication 454 (5.67), 616 (4.30), 672 (4.84), as free base 394 (4.78), 422 (5.64), 436 (5.71), 570 (4.35), 610 (4.88), 666 (4.59); ${ }^{1} \mathrm{H}$ NMR $\left(\mathrm{CH}_{2} \mathrm{Cl}_{2} / \mathrm{TFA}\right) \delta 11.00(\mathrm{~s}, 2 \mathrm{H}), 9.36(\mathrm{~d}, J=7.96 \mathrm{~Hz}$, $4 \mathrm{H}), 8.36(\mathrm{~m}, 4 \mathrm{H}), 8.22(\mathrm{~m}, 8 \mathrm{H}), 7.93(\mathrm{~m}, 4 \mathrm{H}), 7.70(\mathrm{~d}, J=8.21 \mathrm{~Hz}, 4 \mathrm{H}), 0.02(\mathrm{br} \mathrm{s}, 4 \mathrm{H}) ;{ }^{13} \mathrm{C}$ NMR $\left(\mathrm{CDCl}_{3}\right.$ /TFA) $\delta 139.9,139.0,137.4,136.0,133.3,132.9,131.9,130.6,130.4,125.8$, 125.2, 123.5, 114.9, 92.4; ESI HRMS m/z 819.0765; calcd for $\mathrm{C}_{48} \mathrm{H}_{29} \mathrm{~N}_{4} \mathrm{Br}_{2}\left(\mathrm{MH}^{+}\right)$819.0759.

8d-Yield $0.105 \mathrm{~g}(27 \%)$, green powder, $\mathrm{mp}>300^{\circ} \mathrm{C}$; UV/vis $\left(\mathrm{CH}_{2} \mathrm{Cl}_{2} / \mathrm{TFA}\right) \lambda_{\max }(\log \epsilon)$ as dication salt 454 (5.64), 618 (4.40), $672(4.92),\left(\mathrm{CH}_{2} \mathrm{Cl}_{2}\right)$ as free base 394 (4.90), 422 (5.59), 436 (5.62), 570 (4.52), 610 (4.93), 666 (4.72); ${ }^{1} \mathrm{H} \mathrm{NMR}\left(\mathrm{CH}_{2} \mathrm{Cl}_{2} / \mathrm{TFA}\right) \delta 11.04$ (s, 2H), 9.37 $(\mathrm{d}, J=7.96 \mathrm{~Hz}, 4 \mathrm{H}), 8.73(\mathrm{~m}, 4 \mathrm{H}), 8.60(\mathrm{~m}, 4 \mathrm{H}), 8.22(\mathrm{~m}, 4 \mathrm{H}), 7.88(\mathrm{~m}, 4 \mathrm{H}), 7.60(\mathrm{~d}, J=8.21$ $\mathrm{Hz}, 4 \mathrm{H}), 4.25$ (s, 6H), -0.24 (br s, 4H); ${ }^{13} \mathrm{C} \mathrm{NMR}\left(\mathrm{CH}_{2} \mathrm{Cl}_{2} / \mathrm{TFA}\right) \delta 168.1,142.7,139.4,139.2$, 134.8, 133.0, 131.9, 131.8, 131.2, 130.8, 130.7, 125.2, 123.7, 115.0, 92.7, 53.4; LDI-TOF MS m/z 778.11; calcd for $\mathrm{C}_{52} \mathrm{H}_{34} \mathrm{~N}_{4} \mathrm{O}_{4}\left(\mathrm{M}^{+}\right)$778.26. Anal. Calcd for $\mathrm{C}_{52} \mathrm{H}_{34} \mathrm{~N}_{4} \mathrm{O}_{4} \cdot 0.5 \mathrm{Et} 2 \mathrm{O}: \mathrm{C}$, 79.49; H, 4.82; N, 6.87. Found: C, 79.30; H, 4.72; N, 6.74.

$8 \mathrm{e}$-Yield $0.14 \mathrm{~g} \mathrm{(32 \% )}$, green crystals, $\mathrm{mp}>300{ }^{\circ} \mathrm{C}$; UV/vis $\left(\mathrm{CH}_{2} \mathrm{Cl}_{2} / \mathrm{TFA}\right) \lambda_{\max }(\log \epsilon)$ $\left(\mathrm{CH}_{2} \mathrm{Cl}_{2}\right)$ as free base 394 (4.85), 420 (5.51), 438 (5.55), 570 (4.44), 612 (4.86), 666 (4.70); ${ }^{1} \mathrm{H}$ NMR as dication $\left(\mathrm{CH}_{2} \mathrm{Cl}_{2} / \mathrm{TFA}\right) \delta 10.97(\mathrm{~s}, 2 \mathrm{H}), 9.32(\mathrm{~d}, J=7.83 \mathrm{~Hz}, 4 \mathrm{H}), 8.33(\mathrm{~d}$, $J=1.01 \mathrm{~Hz}, 4 \mathrm{H}), 8.15\left(\mathrm{dd}, J_{\text {app }}=7.33 \mathrm{~Hz}, 4 \mathrm{H}\right), 8.13\left(\mathrm{~d}, 2 \mathrm{H}\right.$, overlapped), $7.80\left(\mathrm{dd}, J_{\text {app }}\right) 7.83$ $\mathrm{Hz}, 4 \mathrm{H}), 7.60(\mathrm{~d}, J=8.08 \mathrm{~Hz}, 4 \mathrm{H}), 1.55(\mathrm{~s}, 36 \mathrm{H}), 0.49(\mathrm{br} \mathrm{s}, 4 \mathrm{H}) ;{ }^{1} \mathrm{H}$ NMR as free base $\left(\mathrm{CH}_{2} \mathrm{Cl}_{2}\right) \delta 11.13(\mathrm{~s}, 2 \mathrm{H}), 9.70(\mathrm{~d}, J=6.94 \mathrm{~Hz}, 4 \mathrm{H}), 8.19(\mathrm{~m}, 4 \mathrm{H}), 8.12(\mathrm{~m}+\mathrm{d}$ overlapped, $6 \mathrm{H}), 7.77(\mathrm{~m}, 4 \mathrm{H}), 7.51(\mathrm{~m}, 4 \mathrm{H}), 1.57(\mathrm{~s}, 36 \mathrm{H}),-1.33(\mathrm{br} \mathrm{s}, 2 \mathrm{H}) ;{ }^{13} \mathrm{C} \mathrm{NMR}\left(\mathrm{CH}_{2} \mathrm{Cl}_{2}\right) \delta 151.7$, 141.8, 139.0, 138.9, 137.2, 127.2, 127.0, 126.7, 125.3, 122.0, 120.8, 117.8, 92.8, 35.4, 31.7; ESI HRMS m/z 887.5054; calcd for $\mathrm{C}_{64} \mathrm{H}_{63} \mathrm{~N}_{4}\left(\mathrm{MH}^{+}\right)$887.5053.

\section{Pd-8a}

Porphyrin 8a (11 mg, $0.017 \mathrm{mmol})$ was dissolved in PhCN (5 mL) and heated to about $100^{\circ}$ C. $\mathrm{PdCl}_{2}(10 \mathrm{mg}, 0.056 \mathrm{mmol})$ was added, and the mixture was refluxed under Ar. The reaction was stopped when the absorption bands of the free base porphyrin disappeared. Complete conversion required refluxing for about $2 \mathrm{~h}$. The solvent was evaporated in vacuum. The remaining emerald green solid was dissolved in a small volume of $\mathrm{CH}_{2} \mathrm{Cl}_{2}(\sim 3 \mathrm{~mL})$ and chromatographed a silica gel column $\left(\varnothing 2 \times 20 \mathrm{~cm}\right.$, eluent: $\left.\mathrm{CH}_{2} \mathrm{Cl}_{2}\right)$. The emerald green band 
was collected, and evaporation of the solvent gave Pd-8a as a dark green powder: yield $11 \mathrm{mg}$ $(86 \%) ;{ }^{1} \mathrm{H}$ NMR $\left(\mathrm{DMF}-d_{7}, 100{ }^{\circ} \mathrm{C}\right) \delta 11.11(\mathrm{~s}, 2 \mathrm{H}), 9.75(\mathrm{~s}, 4 \mathrm{H}), 8.64\left(\mathrm{aa}^{\prime} \mathrm{bb}, J_{1}=6.83 \mathrm{~Hz}\right.$, $\left.J_{2}=1.46 \mathrm{~Hz}, 4 \mathrm{H}\right), 8.30(\mathrm{t}, J=6.8 \mathrm{~Hz}, 4 \mathrm{H}), 8.06$ (overlapped with solvent), $7.60(\mathrm{~m}, 4 \mathrm{H}), 7.23$ $(\mathrm{d}, J=7.71 \mathrm{~Hz}, 4 \mathrm{H})$; MALDI-TOF $(\mathrm{m} / \mathrm{z})$ calcd for $\mathrm{C}_{48} \mathrm{H}_{28} \mathrm{~N}_{4} \mathrm{O}_{12} \mathrm{Pd} 767.2$, found $770.9[\mathrm{M}+$ $\left.\mathrm{H}^{+}\right]$.

\section{Acknowledgment}

Support of the Grants RFBR-04-03-32650 and RFBR-07-03-01121 from Russian Foundation of Basic Research and the Grants EB007279 and HL081273 from the NIH USA is gratefully acknowledged. We thank Dr. Alexei Averin (MSU) for help with NMR and MALDI analysis, and Dr. Thomas Troxler (Penn RLBL) for assistance with the femtosecond laser experiments.

\section{References}

(1)(a). Guha S, Kang K, Porter P, Roach JF, Remy DE, Aranda FJ, Rao DVGLN. Opt. Lett 1992;17:264266. (b) Brunel M, Chaput F, Vinogradov SA, Campagne B, Canva M, Boilot JP, Brun A. Chem. Phys 1997;218:301-307. (c) Aramaki S, Sakai Y, Ono N. Appl. Phys. Lett 2004;84:2085-2087. (d) Shea PB, Johnson AR, Ono N, Kanicki J. IEEE Trans. Electron Dev 2005;52:1497-1503. (e) Borek C, Hanson K, Djurovich PI, Thompson ME, Aznavour K, Bau R, Sun YR, Forrest SR, Brooks J, Michalski L, Brown J. Angew. Chem., Int. Ed 2007;46:1109-1112.

(2)(a). Vinogradov SA, Wilson DFJ. Chem. Soc., Perkin Trans. 2 1995:103-111. (b) Dunphy I, Vinogradov SA, Wilson DF. Anal. Biochem 2002;310:191-198. [PubMed: 12423638] (c) Finikova OS, Galkin A, Rozhkov VV, Cordero M, Hägerhäll C, Vinogradov SA. J. Am. Chem. Soc 2003;125:4882-4893. [PubMed: 12696908] (d) Rietveld IB, Kim E, Vinogradov SA. Tetrahedron 2003;59:3821-3831. (e) Apreleva SV, Wilson DF, Vinogradov SA. Appl. Opt 2006;45:8547-8559. [PubMed: 17086268] (f) Wilson DF, Lee WMF, Makonnen S, Finikova O, Apreleva S, Vinogradov SA. J. Appl. Physiol 2006;101:1648-1656. [PubMed: 16888050] (g) Finikova OS, Troxler T, Senes A, DeGrado WF, Hochstrasser RM, Vinogradov SA. J. Phys. Chem. A 2007;111:6977-6990. [PubMed: 17608457]

(3)(a). Baluschev S, Yakutkin V, Miteva T, Avlasevich Y, Chernov S, Aleshchenkov S, Nelles G, Cheprakov A, Yasuda A, Mullen K, Wegner G. Angew. Chem., Int. Ed 2007;46:7693-7696. (b) Baluschev S, Yakutkin V, Wegner G, Miteva T, Nelles G, Yasuda A, Chernov S, Aleshchenkov S, Cheprakov A. Appl. Phys. Lett 2007;90:181103. (c) Baluschev S, Yakutkin V, Miteva T, Wegner G, Roberts T, Nelles G, Yasuda A, Chernov S, Aleshchenkov S, Cheprakov A. New J. Phys 2008;10:1-12.

(4)(a). Friedberg JS, Skema C, Baum ED, Burdick J, Vinogradov SA, Wilson DF, Horan AD, Nachamkin I. J. Antimicrob. Chemother 2001;48:105-107. [PubMed: 11418518] (b) Ongayi O, Gottumukkala V, Fronczek FR, Vicente MGH. Bioorg. Med. Chem. Lett 2005;15:1665-1668. [PubMed: 15745818] (c) Gottumukkala V, Ongayi O, Baker DG, Lomax LG, Vicente MGH. Bioorg. Med. Chem 2006;14:1871-1879. [PubMed: 16298134]

(5)(a). Barrett PA, Linstead RP, Rundall FG, Tuey GAP. J. Chem. Soc 1940:1079-1092. (b) Bender CO, Bonnett R, Smith RG. Chem. Commun 1969:345-346. (c) Bender CO, Bonnett R, Smith RG. J. Chem. Soc. C 1970:1251-1257. (d) Bender CO, Bonnett R, Smith RG. J. Chem. Soc., Perkin Trans. 1 1972:771-776. (e) Remy DE. Tetrahedron Lett 1983;24:1451-1454. (f) Kopranenkov VN, Makarova EA, Luk'yanets EA. Zh. Obshch. Khim 1981;51:2727-2730. (g) Kopranenkov VN, Makarova EA, Dashkevich SN, Luk'yanets EA. Khim. Geterotsikl. Soed 1988:773-779. (h) Galanin NE, Kudrik EV, Shaposhnikov GP. Russ. J. Gen. Chem 1997;67:1306-1309. (i) Galanin NE, Kudrik EV, Shaposhnikov GP. Russ. J. Gen. Chem 2002;72:1119-1122. (j) Ichimura K, Sakruagi M, Morii H, Yasuike M, Fukui M, Ohno O. Inorg. Chim. Acta 1991;182:83-86.

(6)(a). Lash TD. Energy Fuels 1993;7:166-171. (b) Manley JM, Roper TJ, Lash TD. J. Org. Chem 2005;70:874-891. [PubMed: 15675845]

(7)(a). Finikova OS, Cheprakov AV, Beletskaya IP, Vinogradov SA. Chem. Commun 2001:261-262. (b) Finikova OS, Chernov SY, Cheprakov AV, Filatov MA, Vinogradov SA, Beletskaya IP. Dokl. Chem 2003;391:222-224. (c) Finikova OS, Cheprakov AV, Beletskaya IP, Carroll PJ, Vinogradov SA. J. Org. Chem 2004;69:522-535. [PubMed: 14725469] 
(8)(a). Finikova OS, Cheprakov AV, Carroll PJ, Vinogradov SA. J. Org. Chem 2003;68:7517-7520. [PubMed: 12968910] (b) Finikova OS, Aleshchenkov SE, Briñas RP, Cheprakov AV, Carroll PJ, Vinogradov SA. J. Org. Chem 2005;70:4617-4628. [PubMed: 15932297]

(9)(a). Lindsey JS, Hsu HC, Schreiman IC. Tetrahedron Lett 1986;27:4969-4970. (b) Lindsey JS, Schreiman IC, Hsu HC, Kearney PC, Marguerettaz AM. J. Org. Chem 1987;52:827.

(10). Finikova OS, Cheprakov AV, Vinogradov SA. J. Org. Chem 2005;70:9562-9572. [PubMed: 16268634]

(11). Filatov MA, Cheprakov AV, Beletskaya IP. Eur. J. Org. Chem 2007:3468-3475.

(12)(a). Cheng RJ, Chen YR, Chuang CE. Heterocycles 1992;34:1-4.There are several reports mentioning synthesis of 5,15-diphenyltetrabenzoporphyrin using the high-temperature template condensation method. The obtained compounds, however, have never been unambiguously characterized (b) Ichimura K, Sakuragi M, Morii H, Yasuike M, Fukui M, Ohno O. Inorg. Chim. Acta 1990;176:31-3. (c) Kudrik EV, Islyaikin MK, Frantseva SV. Zh. Obshch. Khim 1997;67:1202-1205.

(13). Senge MO, Bischoff I. Heterocycles 2005;65:879-886.The nucleophilic substitution method, developed by Senge et alleads to 5-monoaryl and 5,10-Ar 2 TBPs, but not 5,15-Ar 2 TBPsSenge MO, Bischoff I. Tetrahedron Lett 2004;45:1647-1650.

(14)(a). Gouterman M. J. Mol. Spectrosc 1961;6:138-163. (b) Ehrenberg B, Johnson FM. Spectrochim. Acta 1990;46a:1521-1532.

(15)(a). Martinsen J, Pace LJ, Phillips TE, Hoffman BM, Ibers JA. J. Am. Chem. Soc 1982;104:83-91. (b) Liou K, Ogawa MY, Newcomb TP, Quirion G, Lee MH, Poirier M, Halperin WP, Hoffman BM, Ibers JA. Inorg. Chem 1989;28:3889-3896. (c) Liou KY, Newcomb TP, Heagy MD, Thompson JA, Heuer WB, Musselman RL, Jacobsen CS, Hoffman BM, Ibers JA. Inorg. Chem 1992;31:4517-4523. (d) Murata K, Liou KK, Thompson JA, McGhee EM, Rende DE, Ellis DE, Musselman RL, Hoffman BM, Ibers JA. Inorg. Chem 1997;36:3363-3369. [PubMed: 11670003]

(16)(a). Bajema L, Gouterman M, Rose C. J. Mol. Spectrosc 1971;39:421-431. (b) Tsvirko MP, Sapunov VV, Soloviyev KN. Opt. Spektrosk 1973;34:1094-1100. (c) Edwards L, Gouterman M, Rose CB. J. Am. Chem. Soc 1976;98:7638-7641. [PubMed: 993497] (d) Aartsma TJ, Gouterman M, Jochum C, Kwiram AL, Pepich BV, Williams LD. J. Am. Chem. Soc 1982;104:6278-6283. (e) Aaviksoo J, Frieberg A, Savikhin S, Stelmakh GF, Tsvirko MP. Chem. Phys. Lett 1984;111:275-278.

(17). Treibs A, Häberle N. Justus Liebigs Ann. Chem 1968;718:183-207. [PubMed: 5704489]

(18). Collman JP, Chong AO, Jameson GB, Oakley RT, Rose E, Schmittou ER, Ibers JA. J. Am. Chem. Soc 1981;103:516-533.

(19)(a). Karotki A, Drobizhev M, Dzenis Y, Taylor PN, Anderson HL, Rebane A. Phys. Chem. Chem. Phys 2004;6:7-10. (b) Lin VSY, DiMagno SG, Therien MJ. Science 1994;264:1105. [PubMed: 8178169] (c) Hori T, Nakamura Y, Aratani N, Osuka A. J. Organomet. Chem 2007;692:148-155. (d) Aimi J, Oya K, Tsuda A, Aida T. Angew. Chem., Int. Ed 2007;46:2031-2035. (e) Frampton MJ, Accorsi G, Armaroli N, Rogers JE, Fleitz PA, McEwan KJ, Anderson HL. Org. Biomol. Chem 2007;5:1056-1061. [PubMed: 17377659]

(20)(a). Inokuma Y, Osuka A. Org. Lett 2004;6:3663-3666. [PubMed: 15469318] (b) Shinmori H, Kajiwara T, Osuka A. Tetrahedron Lett 2001;42:3617-3620.

(21). Kuciauskas D, Liddell PA, Lin S, Johnson TE, Weghorn SJ, Lindsey JS, Moore AL, Moore TA, Gust D. J. Am. Chem. Soc 1999;121:8604-8614.

(22)(a). Manka JS, Lawrence DS. Tetrahedron Lett 1989;30:7341-7344. (b) Tanaka S, Shirakawa M, Kaneko K, Takeuchi M, Shinkai S. Langmuir 2005;21:2163-2172. [PubMed: 15752003] (c) Teo TL, Vetrichelvan M, Lai YH. Org. Lett 2003;5:4207-4210. [PubMed: 14572286]

(23)(a). Diebold A, Fischer J, Weiss R. New J. Chem 1996;20:959-970. (b) Jaquinod L, Prevot L, Fischer J, Weiss R. Inorg. Chem 1998;37:1142-1149. [PubMed: 11670318] (c) Shao XB, Jiang XK, Wang XZ, Li ZT, Zhu SZ. Tetrahedron 2003;59:4881-4889. (d) Comte C, Gros CP, Koeller S, Guilard R, Nurco DJ, Smith KM. New J. Chem 1998;22:621-626. (e) Rose E, Quelquejeu M, Pandian RP, Lecas-Nawrocka A, Vilar A, Ricart G, Collman JP, Wang Z, Straumanis A. Polyhedron 2000;19:581-586. (f) Rose E, Lecas A, Quelquejeu M, Kossanyi A, Boitrel B. Coord. Chem. Rev 1998;180:1407-1431. 
(24)(a). Gunter MJ, Jeynes TP, Turner P. Eur. J. Org. Chem 2004:193-208. (b) Gunter MJ, Farquhar SM, Jeynes TP. Org. Biomol. Chem 2003;1:4097-4112. [PubMed: 14664400] (c) Gunter MJ, Merican Z. Supramol. Chem 2005; 17:521-528.

(25)(a). Liddell PA, Kodis G, Kuciauskas D, Andreasson J, Moore AL, Moore TA, Gust D. Phys. Chem. Chem. Phys 2004;6:5509-5515. (b) Wrobel D, Graja A. J. Photochem. Photobiol. A 2006;183:7988. (c) Kuciauskas D, Liddell PA, Lin S, Stone SG, Moore AL, Moore TA, Gust D. J. Phys. Chem. B 2000;104:4307-4321. (d) Laudien R, Yoshida I, Nagamura T. J. Chem. Soc., Perkin Trans. 2 2002:1772-1777. (e) Shiratori H, Ohno T, Nozaki K, Yamazaki I, Nishimura Y, Osuka A. J. Org. Chem 2000;65:8747-8757. [PubMed: 11112599] (f) Osuka A, Shin JY, Yoneshima R, Shiratori H, Ohno T, Nozaki K, Nishimura Y, Yamazaki I, Taniguchi S, Shimizu T, Okada T. J. Porphyrins Phthalocyanines 1999;3:729-741. (g) Zhang XX, Lippard SJ. J. Org. Chem 2000;65:5298-5305. [PubMed: 10993359]

(26). Hodgson MJ, Borovkov VV, Inoue Y, Arnold DP. J. Organomet. Chem 2006;691:2162-2170.

(27)(a). Banfi S, Caruso E, Fieni E, Buccafurni L, Gariboldi MB, Ravizza R, Monti E. J. Porphyrins Phthalocyanines 2006;10:1319-1326. (b) Banfi S, Caruso E, Buccafurni L, Murano R, Monti E, Gariboldi M, Papa E, Gramatica P. J. Med. Chem 2006;49:3293-3304. [PubMed: 16722648]

(28)(a). Mizutani T, Ema T, Yoshida T, Kuroda Y, Ogoshi H. Inorg. Chem 1993;32:2072-2077. (b) Ogoshi H, Mizutani T. Acc. Chem. Res 1998;31:81-89. (c) Mamardashvili GM, Storonkina OE, Mamardashvili NZ. Russ. J. Gen. Chem 2004;74:1446-1450. (d) Comte C, Gros CP, Koeller S, Guilard R, Nurco DJ, Smith KM. New J. Chem 1998;22:621-626.

(29)(a). Dandliker PJ, Diederich F, Gross M, Knobler CB, Louati A, Sanford EM. Angew. Chem., Int. Ed. Engl 1994;33:1739-1742. (b) Dandliker PJ, Diederich F, Gisselbrecht JP, Louati A, Gross M. Angew. Chem., Int. Ed. Engl 1996;34:2725-2728. (c) Collman JP, Fu L, Zingg A, Diederich F. Chem. Commun 1997:193-194.

(30)(a). Bejune SA, Shelton AH, McMillin DR. Inorg. Chem 2003;42:8465-8475. [PubMed: 14658901] (b) McMillin DR, Shelton AH, Bejune SA, Fanwick PE, Wall RK. Coord. Chem. Rev 2005;249:1451-1459.

(31)(a). Ogoshi H, Sugimoto H, Nishiguchi T, Watanabe T, Matsuda Y, Yoshida Z. Chem. Lett 1978:2932. (b) Osuka A, Nagata T, Kobayashi F, Maruyama K. J. Heterocycl. Chem 1990;27:1657-1659. (c) Gunter MJ, Mander LN. J. Org. Chem 1981;46:4792-4795. (d) Young R, Chang CK. J. Am. Chem. Soc 1985;107:898-909. (e) Manka JS, Lawrence DS. Tetrahedron Lett 1989;30:6989-6992. (f) Osuka A, Kobayashi F, Maruyama K. Bull. Chem. Soc. Jpn 1991;64:1213-1225.

(32)(a). Liddell PA, Kodis G, Kuciauskas D, Andreasson J, Moore AL, Moore TA, Gust D. Phys. Chem. Chem. Phys 2004;6:5509-5515.Other examples (b) Inokuma Y, Osuka A. Org. Lett 2004;6:36633666. [PubMed: 15469318] (c) Gunter MJ, Jeynes TP, Turner P. Eur. J. Org. Chem 2004;193:208. (d) Shinmori H, Kajiwara T, Osuka A. Tetrahedron Lett 2001;42:3617-3620. (e) Shiratori H, Ohno T, Nozaki K, Yamazaki I, Nishimura Y, Osuka A. J. Org. Chem 2000;65:8747-8757. [PubMed: 11112599] (f) Rhee SW, Na YH, Do Y, Kim J. Inorg. Chim. Acta 2000;309:49-56. (g) Plieger PG, Burrell AK, Jameson GB, Officer DL. Dalton Trans 2004:319-326. [PubMed: 15356730] (h) Zhang XX, Fuhrmann P, Lippard SJ. J. Am. Chem. Soc 1998;120:10260-10261. (i) Noss L, Liddell PA, Moore AL, Moore TA, Gust D. J. Phys. Chem. B 1997;101:458-465. (j) Lecas A, Boitrel B, Rose E. Tetrahedron Lett 1992;33:481-484. (k) Nagata T. Bull. Chem. Soc. Jpn 1991;64:3005-3016.

(33)(a). Arsenault GP, Bullock E, MacDonald SF. J. Am. Chem. Soc 1960;82:4384. (b) Markovac A, MacDonald SF. Can. J. Chem 1965;43:3364.

(34)(a). Baldwin JE, Crossley MJ, Klose T, Orear EA, Peters MK. Tetrahedron 1982;38:27-39. (b) Boyle RW, Bruckner C, Posakony J, James BR, Dolphin D. Org. Synth 1999;76:287-293. (c) Boitrel B, Lecas A, Renko Z, Rose E. New J. Chem 1989;13:73-99. (d) Boitrel B, Lecas A, Renko Z, Rose E. Chem. Commun 1985:1820-1821. (e) Lecas-Nawrocka A, Levisalles J, Mariacher C, Renko Z, Rose E. Can. J. Chem 1984;62:2054-2058. (f) Lecas-Nawrocka A, Levisalles J, Renko Z, Rose E. Tetrahedron Lett 1984;25:1563-1566.

(35). Hombrecher HK, Horter G, Arp C. Tetrahedron 1992;48:9451-9460.

(36). Jolicoeur B, Chapman EE, Thompson A, Lubell WD. Tetrahedron 2006;62:11531-11563.

(37)(a). Wilson GS, Anderson HL. Synlett 1996:1039-1040.Scrambling has been extensively investigated for regular $\mathrm{A}_{2} \mathrm{~B}_{2}$ porphyrins (b) Littler BJ, Ciringh Y, Lindsey JS. J. Org. Chem 1999;64:2864-2872. [PubMed: 11674358] 
(38). Novak BH, Lash TD. J. Org. Chem 1998;63:3998-4010.

(39)(a). Zavyalov SI, Skoblik TI. Bull. Acad. Sci. USSR DiV. Chem. Sci 1977;26:25592562.Tetrahydroisoindole derivatives could also be obtained via the modified Knorr chemistry, avoiding expensive malodorous isocyanides required in the Barton-Zard reaction (b) Hombrecher HK, Horter G. Synthesis 1990:389-391. The standard Knorr reaction also can be used (c) May DA. J. Org. Chem 1992;57:4820-4828.

(40). Zaidi SHH, Fico RM Jr. Lindsey JS. Org. Process Res. Dev 2006;10:118-134. Bu 4 NCl has been occasionally used in the porphyrin syntheses as a water scavenging agent

(41)(a). Archibald JL, Walker DM, Shaw KB, Markovac A, F. MS. Can. J. Chem 1966;44:345. (b) Senge MO, Medforth CJ, Forsyth TP, Lee DA, Olmstead MM, Jentzen W, Pandey RK, Shelnutt JA, Smith KM. Inorg. Chem 1997;36:1149-1163. [PubMed: 11669682]

(42)(a). Dolphin DJ. Heterocycl. Chem 1970;7:275. (b) Harmjanz M, Gill HS, Scott MJ. J. Org. Chem 2001;66:5374-5383. [PubMed: 11485458] (c) Bonomo L, Solari E, Scopelliti R, Latronico M, Floriani C. Chem. Commun 1999:2227-2228. (d) Botulinski A, Buchler JW, Abbes NE, Scheidt WR. Justus Liebigs Ann. Chem 1987:305-309. (e) Senge MO, Runge S, Speck M, Ruhlandt-Senge K. Tetrahedron 2000;56:8927-8932.

(43). Wood TE, Thompson A. Chem. Rev 2007;107:1831-1861. [PubMed: 17430001] and references therein

(44). Osuka A, Shimidzu H. Angew. Chem., Int. Ed. Engl 1997;36:135-137.

(45). Finikova OS, Cheprakov AV, Carroll PJ, Dalosto S, Vinogradov SA. Inorg. Chem 2002;41:69446946. [PubMed: 12495329]

(46). Filatov MA, Cheprakov AV. J. Porphyrins Phthalocyanines 2006;10:629.Presented in part at ICPP-4 (2006), Rome, Italy

(47). Ogliaruso MA, Romanell MG, Becker EI. Chem. Rev 1965;65:261-367.

(48). Schenck GO. Chem. Ber 1947;80:226-231.

(49). Fuhrhop JH, Hosseinpour D. Justus Liebigs Ann. Chem 1985:689-695.

(50)(a). Barton D, Zard S. Chem. Commun 1985:1098-1100. (b) Barton D, Kervagoret J, Zard S. Tetrahedron 1990;46:7587-7598. (c) Abel Y, Haake E, Haake G, Schmidt W, Struve D, Walter A, Montforts FP. HelV. Chim. Acta 1998;81:1978-1996.

(51)(a). Nguyen KA, Pachter R. J. Chem. Phys 2001;114:10757-10767. (b) Rosa A, Ricciardi G, Baerends EJ, van Gisbergen SJA. J. Phys. Chem. A 2001;105:3311-3327.

(52). Vogler A, Kunkely H, Rethwisch B. Inorg. Chim. Acta 1980;46:101-105.

(53)(a). Karotki A, Drobizhev M, Dzenis Y, Taylor PN, Anderson HL, Rebane A. Phys. Chem. Chem. Phys 2004;6:7-10.For examples see (b) Drobizhev M, Stepanenko Y, Dzenis Y, Karotki A, Rebane A, Taylor PN, Anderson HL. J. Am. Chem. Soc 2004;126:15352-15353. [PubMed: 15563141] (c) Ahn TK, Kim KS, Kim DY, Noh SB, Aratani N, Ikeda C, Osuka A, Kim D. J. Am. Chem. Soc 2006;128:1700-1704. [PubMed: 16448144]

(54). Xu C, Webb WW. J. Opt. Soc. Am. B 1996;13:481-491.

(55). Karstens T, Kobs K. J. Phys. Chem 1980;84:1871-1872.

(56)(a). Goyan RL, Cramb DT. Photochem. Photobiol 2000;72:821-827. [PubMed: 11140272] (b) Karotki A, Khurana M, Lepock JR, Wilson BC. Photochem. Photobiol 2006;82:443-452. [PubMed: 16613497]

(57). Karotki A, Drobizhev M, Kruk M, Spangler C, Nickel E, Mamardashvili N, Rebane A. J. Opt. Soc. Am. B 2003;20:321-325. 

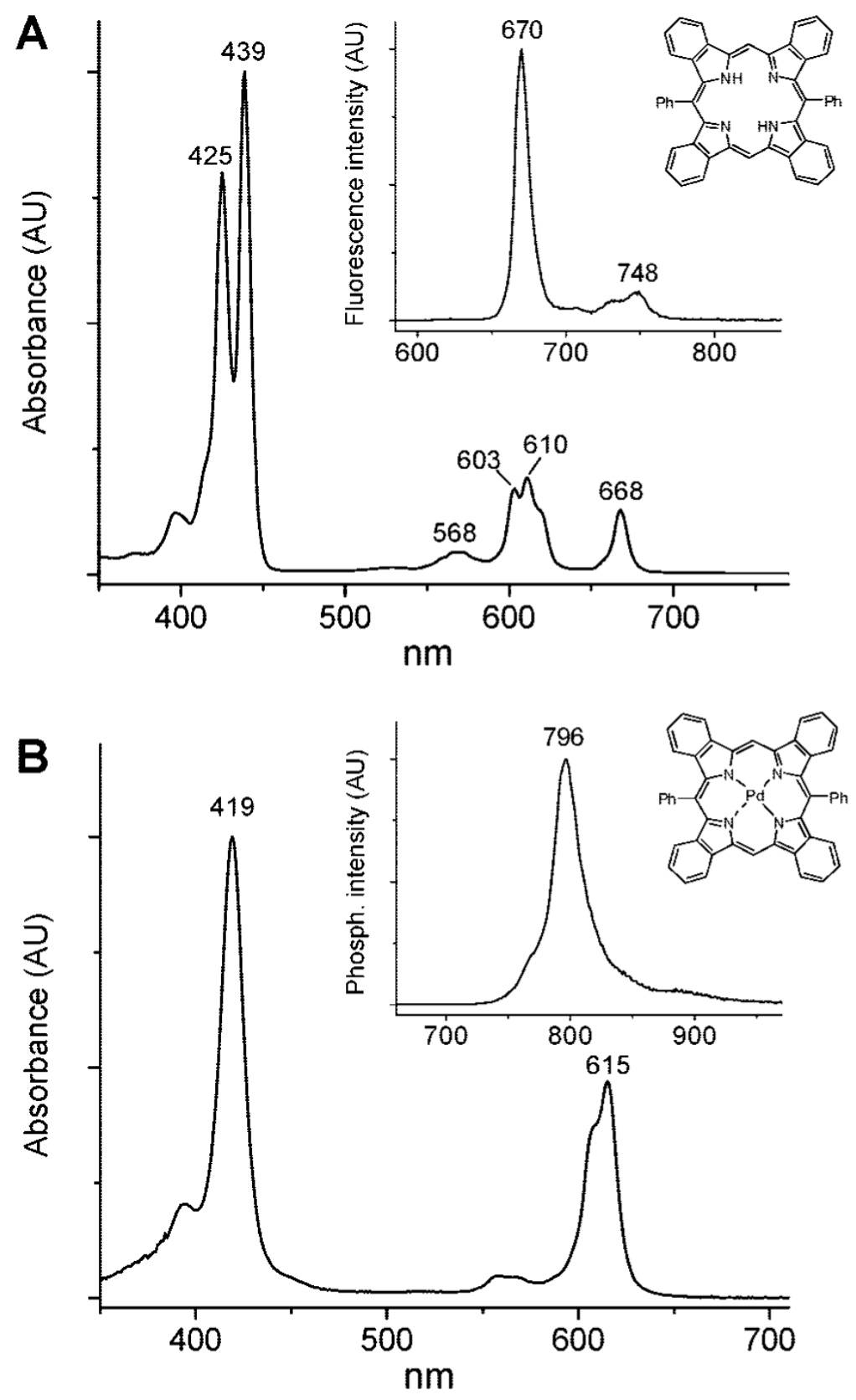

FIGURE 1.

Absorption and emission (insets) spectra of 8a (A) in toluene and of Pd-8a (B) in Ar-purged dimethylacetamide at $23^{\circ} \mathrm{C}$. A (inset): fluorescence, $\lambda_{\mathrm{ex}}=571 \mathrm{~nm}, \varphi_{\text {fluo }}=0.38$. B (inset): phosphorescence, $\lambda_{\mathrm{ex}}=610 \mathrm{~nm}, \varphi_{\text {phos }}=0.19$. 


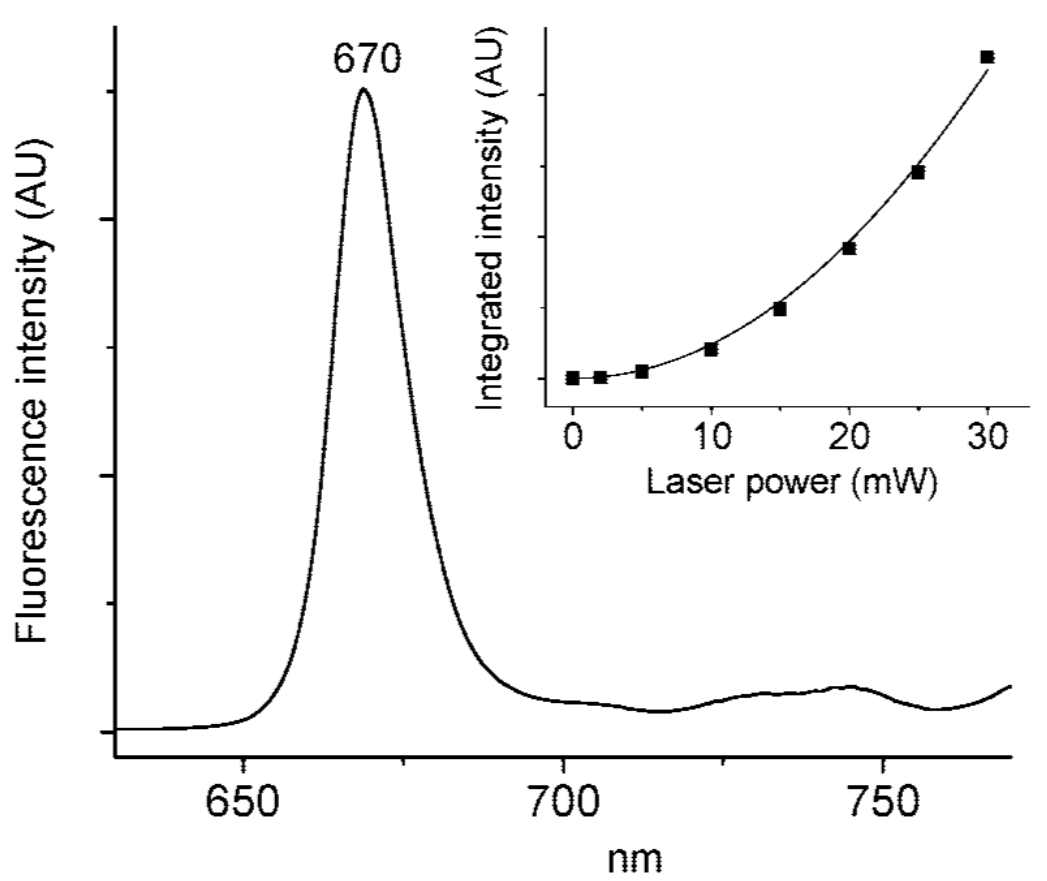

FIGURE 2.

Fluorescence of $8 \mathbf{a}$ induced by two-photon absorption at $840 \mathrm{~nm}$ (110 fs, $76 \mathrm{MHz}$ rep. rate) and its dependence on the incident laser power (inset). The data points (integrated fluorescence intensity $(I)$ versus excitation power $(P)$ ) were fitted to a quadratic function $I(P)=a P^{2}$ (solid line). 

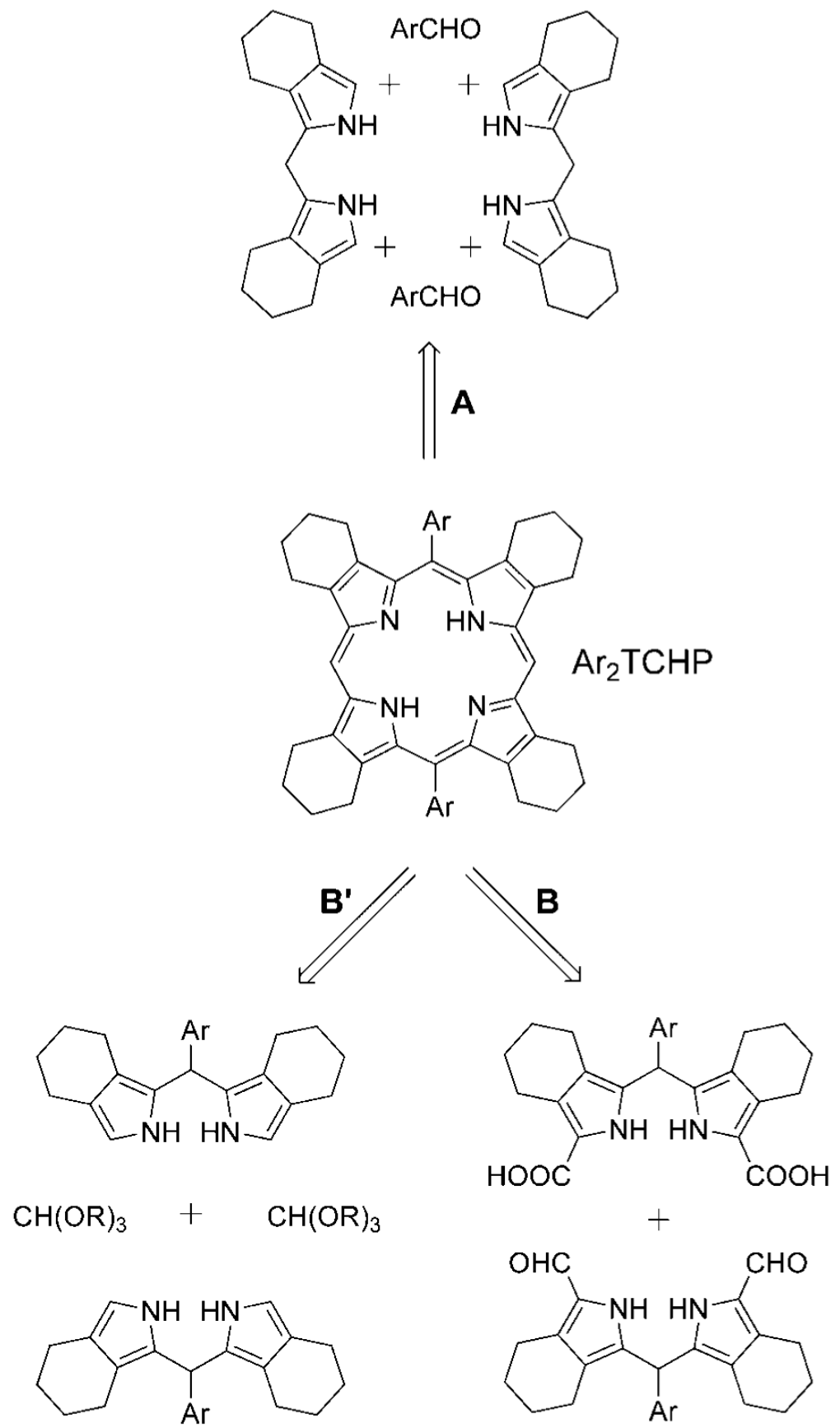

SCHEME 1.

Approaches to $\mathrm{Ar}_{2}$ TCHPs 

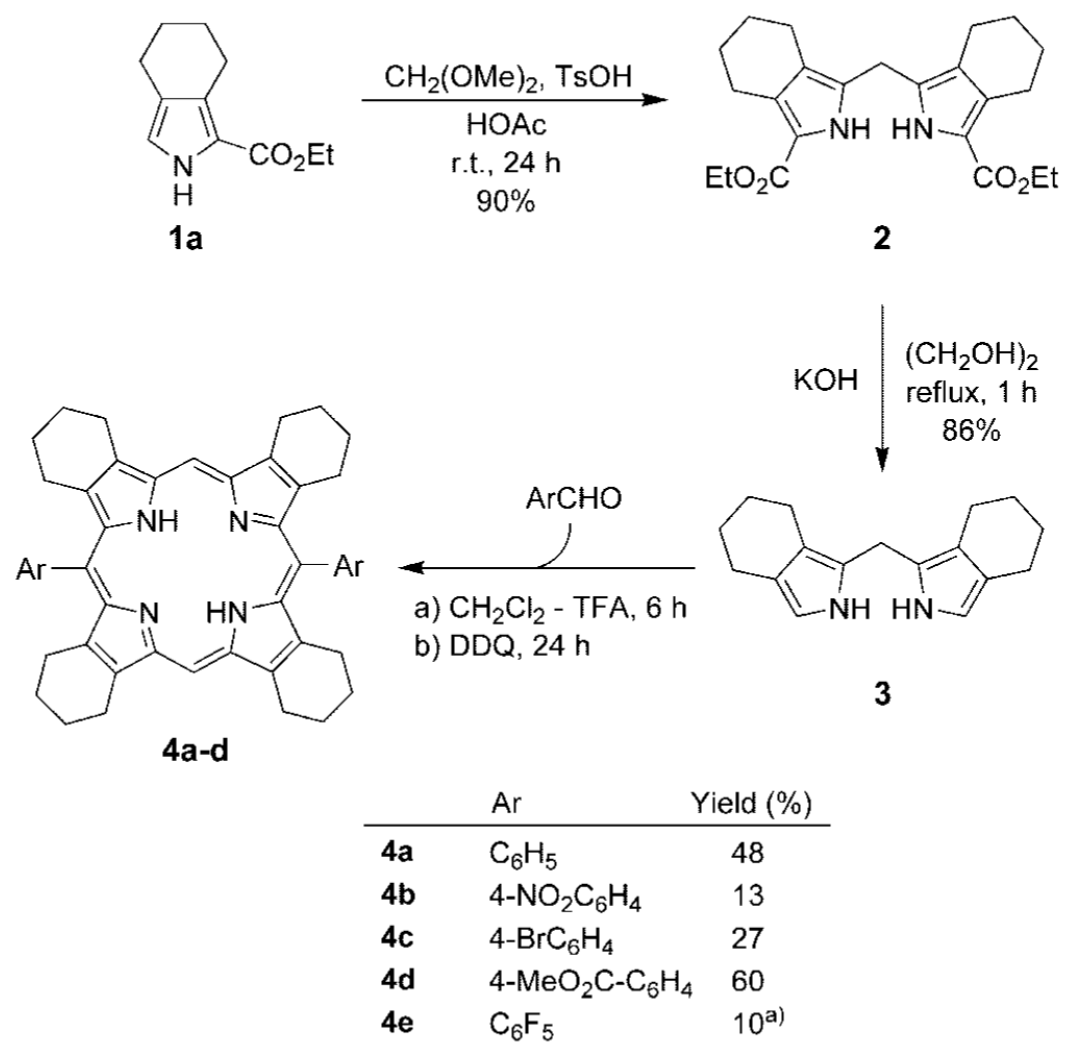

SCHEME 2.

Synthesis of $\mathrm{Ar}_{2}$ TCHPs 4a-e Following Route A (Scheme 1) 


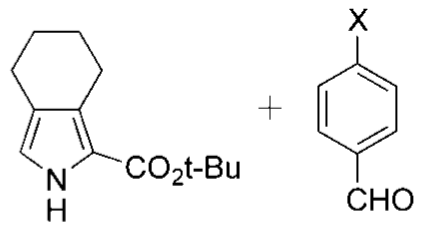

$1 b$

\begin{tabular}{llc} 
& $\mathrm{X}$ & Yield, \% \\
\hline $\mathbf{5 a}$ & $\mathrm{H}$ & 95 \\
$\mathbf{5 b}$ & $\mathrm{NO}_{2}$ & 85 \\
$\mathbf{5 c}$ & $\mathrm{Br}$ & 95
\end{tabular}

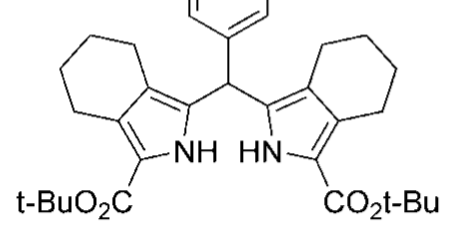

5a-c
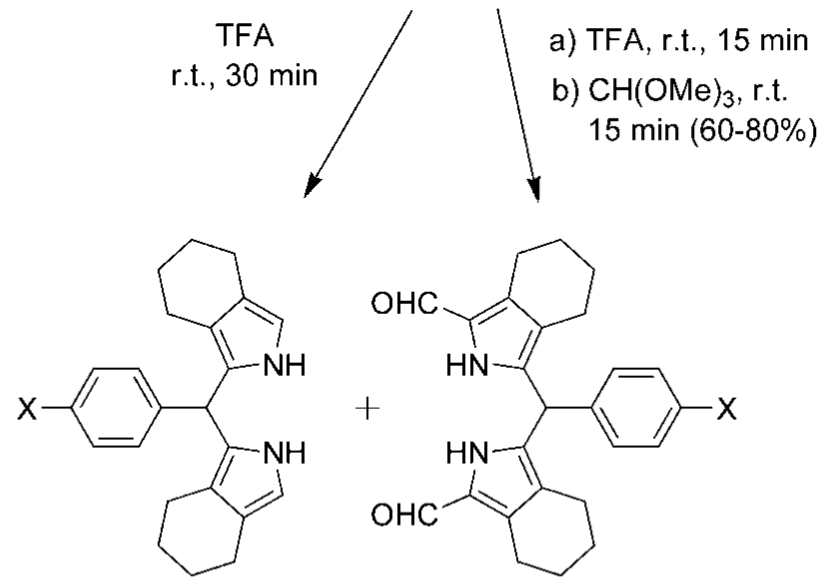

\begin{tabular}{cc} 
& Yield, \% \\
\hline 4a & 20 \\
4b & 26 \\
4c & 17
\end{tabular}

a) TFA, $\mathrm{CH}_{2} \mathrm{Cl}_{2}$, r.t., $21 \mathrm{~h}$

b) DDQ, r.t., 4 h.

SCHEME 3.

Synthesis of $\mathrm{Ar}_{2}$ TCHPs 4a-c from 5-Aryldipyrromethanes Following Route B from Scheme 1 

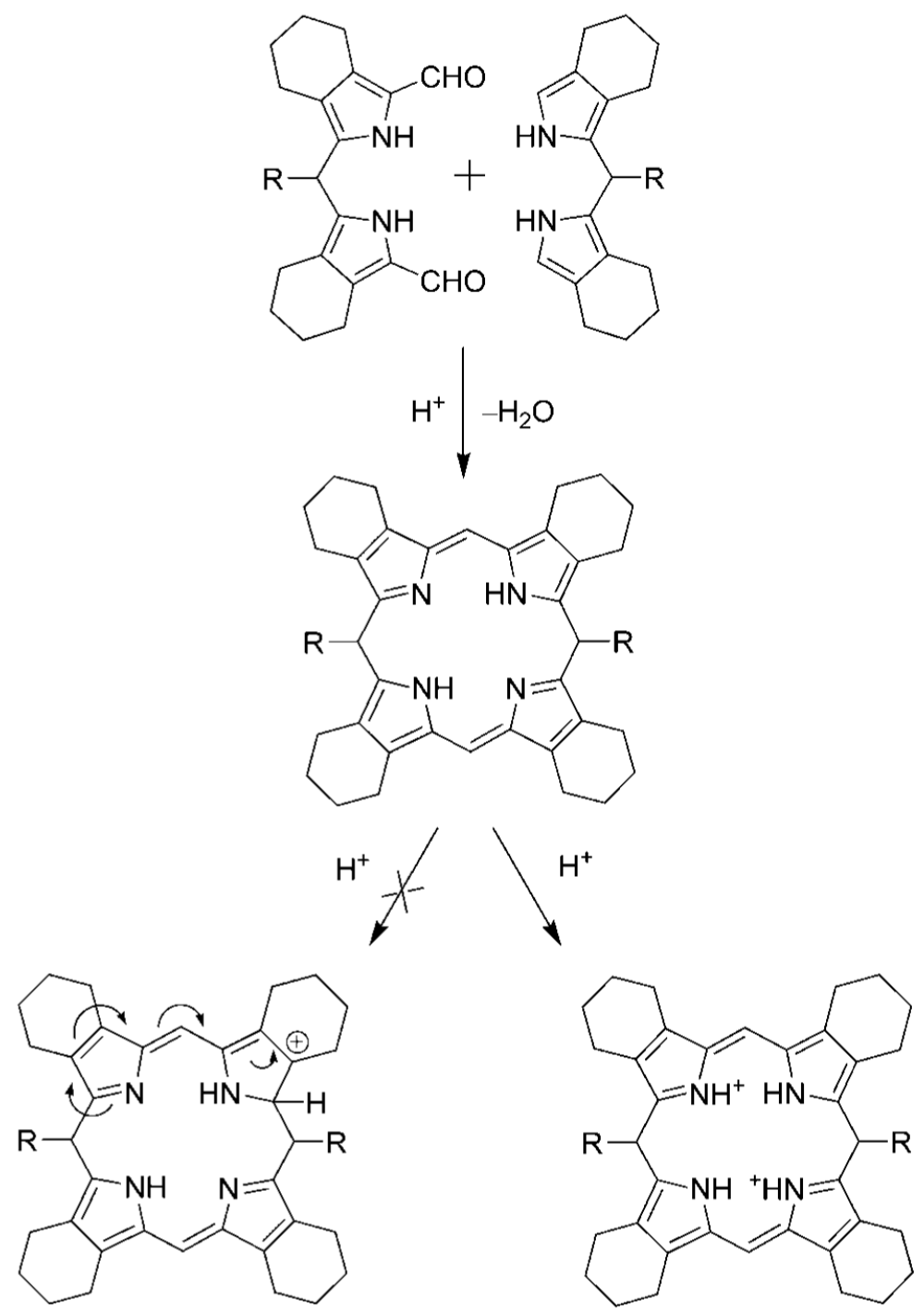

SCHEME 4.

Protonation of Porphodimethenes Occurs Predominantly at Their Pyrrolenine Nitrogens (ipso-Protonation, Required for Scrambling, is Improbable) 


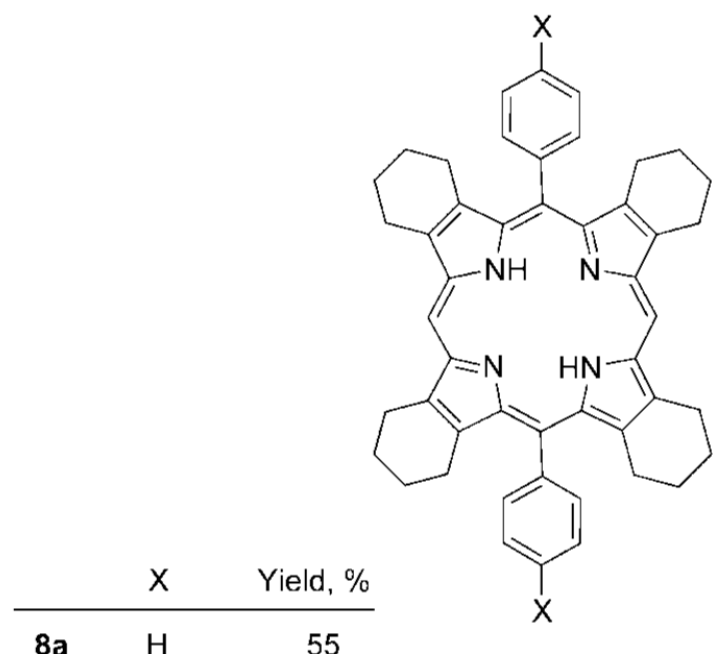

$\begin{array}{lll}\mathbf{8 a} & \mathrm{H} & 55 \\ \mathbf{8 b} & \mathrm{NO}_{2} & <5 \\ \mathbf{8 c} & \mathrm{Br} & 45 \\ \mathbf{8 d} & \mathrm{CO}_{2} \mathrm{Me} & <5\end{array}$

4a-d

8d $\quad \mathrm{CO}_{2} \mathrm{Me} \quad<5$

$180-230^{\circ} \mathrm{C}$
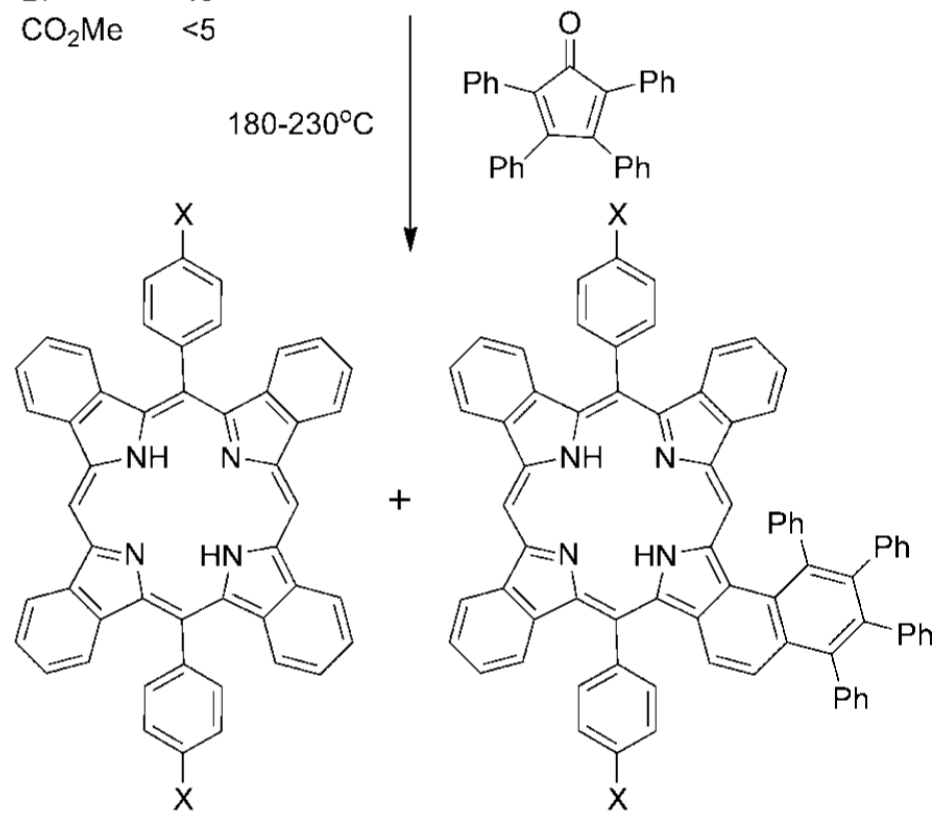

$8 a-d$

SCHEME 5.

Aromatization of $\mathrm{Ar}_{2}$ TCHPs 4a-d by Tetracyclone 
A
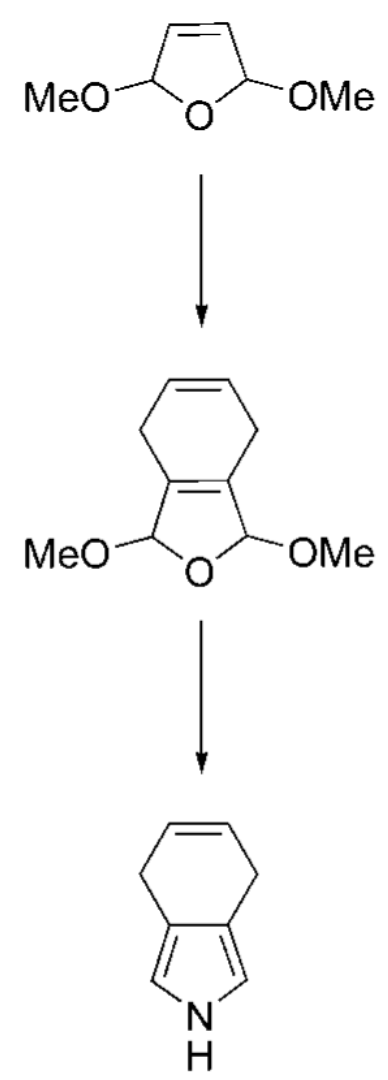

SCHEME 6.

Approaches to 4,7-Dihydroisoindole
B
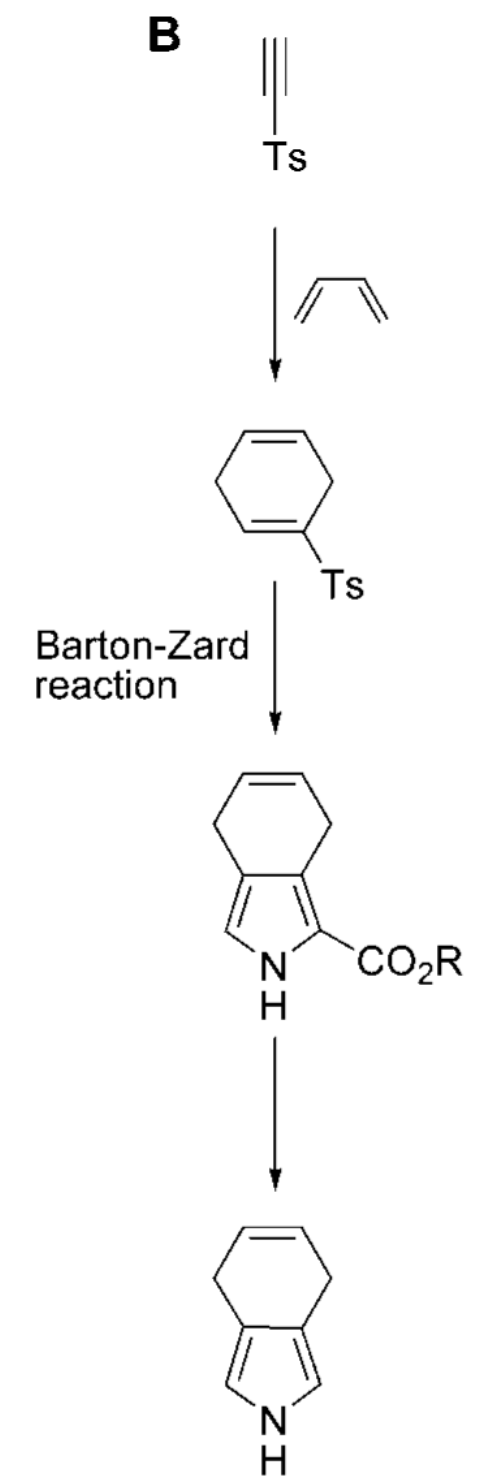


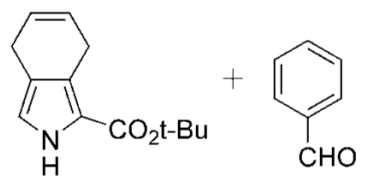

$9 b$

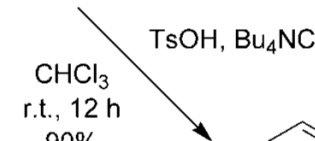
$90 \%$
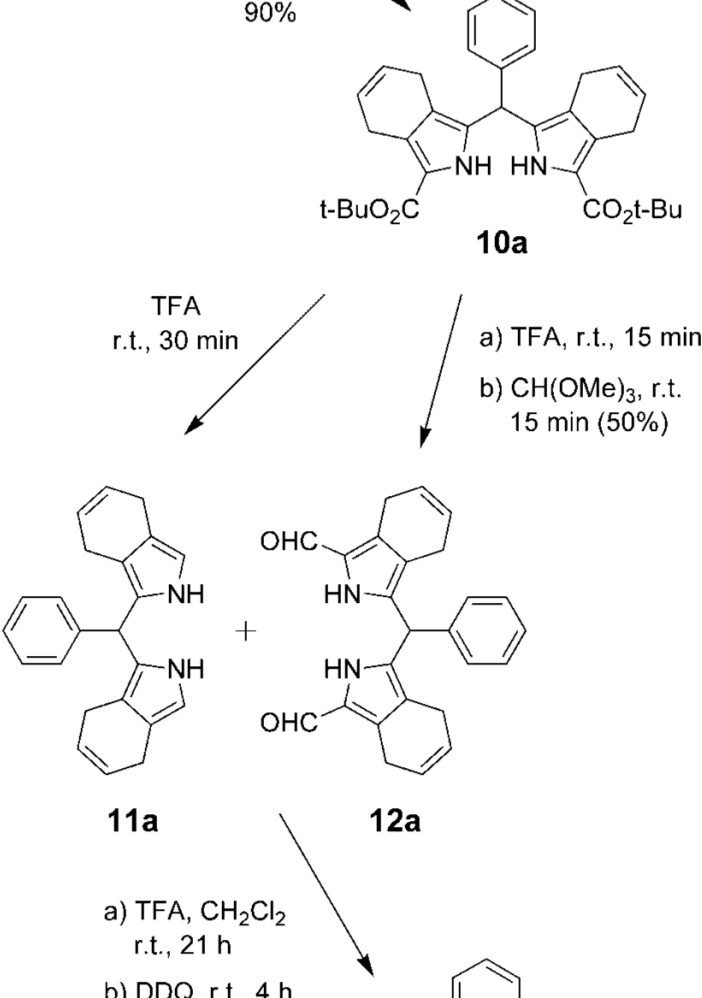

b) $D D Q$, r.t., 4 h.

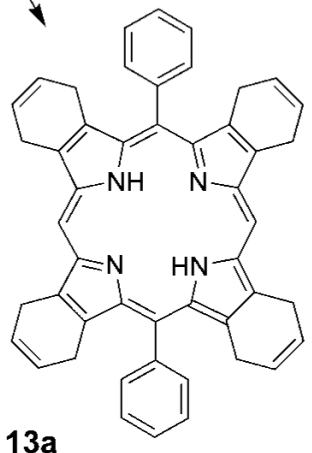

SCHEME 7.

Synthesis of 5,15-Diphenyloctahydro-tetrabenzoporphyrin 

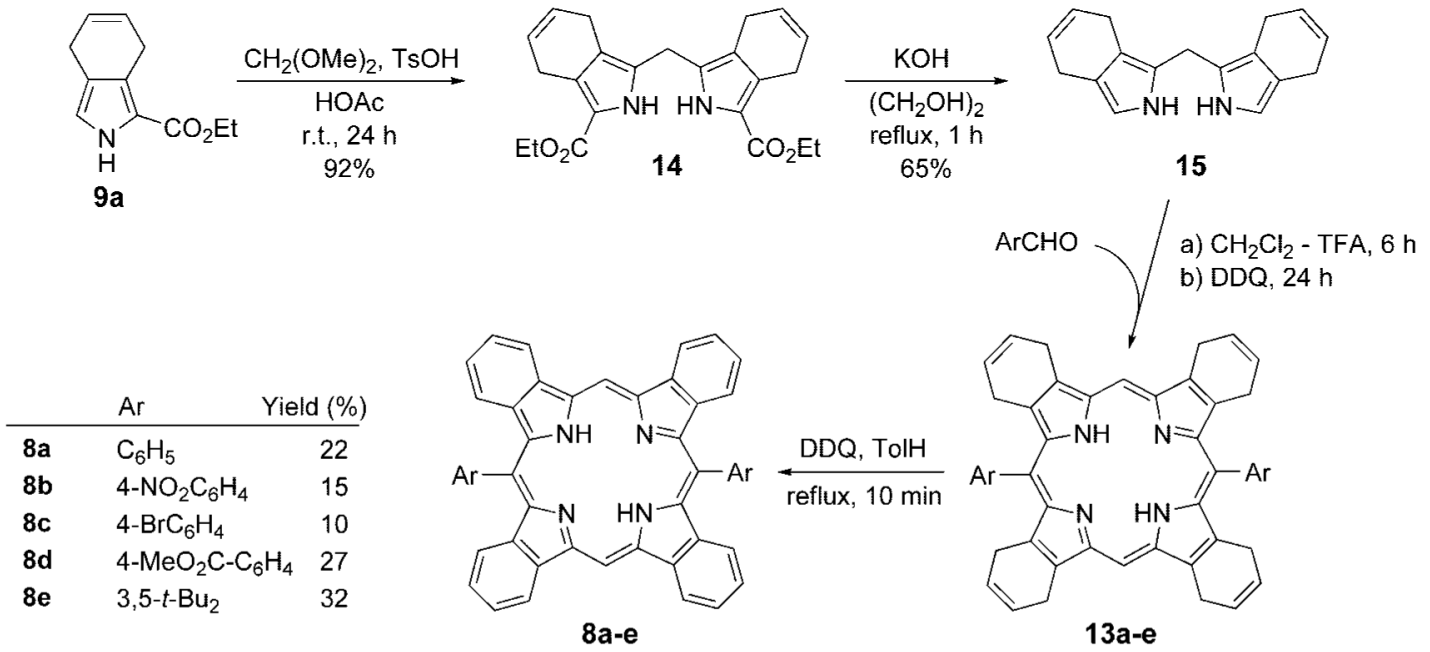

SCHEME 8.

Synthesis of Ar2TBPs via Dihydroisoindole Pathway (Route A from Scheme 1) 